\section{Petrological characteristics of clastic sedimentary rocks from the St. Barbara ore mine in Rude near Samobor}

Rudarsko-geološko-naftni zbornik

(The Mining-Geology-Petroleum Engineering Bulletin) UDC: $550.4: 552.5$

DOI: 10.17794/rgn.2021.1.10

Original scientific paper

\author{
Šime Bilić'; Vesnica Garašić ${ }^{1}$ \\ ${ }^{1}$ Faculty of Mining, Geology and Petroleum Engineering, University of Zagreb, Pierottijeva 6, 10000 Zagreb, Croatia, \\ 0000-0002-1138-0948 \\ ${ }^{2}$ Faculty of Mining, Geology and Petroleum Engineering, University of Zagreb, Pierottijeva 6, 10000 Zagreb, Croatia \\ 0000-0002-4752-6937
}

\begin{abstract}
In the scope of this research, the petrographic and geochemical analyses of clastic sedimentary rocks from the St. Barbara, copper and iron ore mine in Rude near Samobor, have been made, aiming to classify and determine the provenance and environment of formation of clastic sedimentary rocks, as well as the influence of hydrothermal fluids on their properties. Eight samples were collected in total from different locations in the mine. Six of those samples have been studied in detail. The results showed structural and geochemical variability and uneven hydrothermal alteration intensity in the samples. Based on petrographic analyses, three rocks are classified as sublithoarenite, quartz arenite and quartz greywacke. Three of the samples are classified as ore breccia, ore sandstone, and ore silt-sandstone due to the pronounced hydrothermal alterations and ore mineralisation. Comprehensively, petrographic and geochemical analyses indicate that the source rocks of the investigated clastic sedimentary rocks were felsic $(\mathrm{La} / \mathrm{Sc}=0.9-6.2 ; \mathrm{Th} / \mathrm{Sc}=1.3-2.4)$, most probably sedimentary, possibly resedimented rocks. The extent of source rock weathering was very high (Chemical Index of Alteration CIA $=52.1-81.3 \%$ ) and the geotectonic position of the sedimentary basin was very likely to be at the passive continental margin.
\end{abstract}

Keywords:

clastic sedimentary rocks; petrography and geochemistry; provenance; St. Barbara ore mine in Rude; Samobor Mountains

\section{Introduction}

Sedimentary clastic rocks are characterized by mineralogical and chemical composition as well as texture that are directly dependent on: a) the source rocks and their geotectonic position, b) the weathering conditions such as climate, relief and exposure time to the weathering process, c) the mode and duration of transport to the sediment basin and d) the processes that take place after sediment deposition such as diagenesis and hydrothermal alteration. Detailed micropetrographic investigation of clastic rock particles, which include the observation of undulose extinction of monocrystalline or polycrystalline quartz, the presence of feldspar and rock fragments, the determination of their proportions, the identification of particle roundness and their degree of sorting as well as determination of other minerals and mineral alterations represent a classic approach to the study of the origin of clastic sediments. More recently, geochemical composition of clastic rocks has often been in use for this purpose (Bhatia, 1983; Roser and Korsch, 1986; Nesbitt and Young, 1989; McLennan et al. 1993; Herron, 1988; Rahman and Suzuki, 2007;

Corresponding author: Šime Bilić

sime.bilic@rgn.hr
Lužar Oberiter et al., 2012). Thereby, the distribution of concentrations of major elements, rare earth elements and in particular, the elements such as $\mathrm{La}, \mathrm{Ce}, \mathrm{Nd}, \mathrm{Y}, \mathrm{Th}$, $\mathrm{Zr}, \mathrm{Hf}, \mathrm{Nb}$, Ti and Sc have been shown as very suitable chemical provenance indicators of sandstone due to their low mobility in sediment processes (Rahman and Suzuki, 2007).

In the area of the copper and iron mine in Rude near Samobor, numerous geological and petrological research studies have been made (Hacquet, 1784; Vukotinović, 1855, 1873 a, 1873 b; Gorjanović - Kramberger, 1884; Šuklje, 1942; Herak, 1956 and Šikić et al., 1972). The first detailed description of the mineral deposit itself and mineralization was given by Šinkovec (1971). He pointed out that the ore mineralization occurs within the light to dark gray Permian sandstones consisting of detrital grains of quartz, muscovite, biotite, rutile, feldspar, tourmaline, barite, amphibole, apatite and fragments of quartzite, chert, quartz-sericite schist, and sandstone. Śinkovec noted that the matrix usually consists of clay minerals, sericite, quartz and organic matter, while the matrix of chemogenic origin, in the form of siderite, quartz, barite or anhydrite, is rarely present. Recent chemical and mineralogical data related to the ore mineralization of the St. Barbara ore mine was given by Palinkaš et al. (2010), who concluded that this 


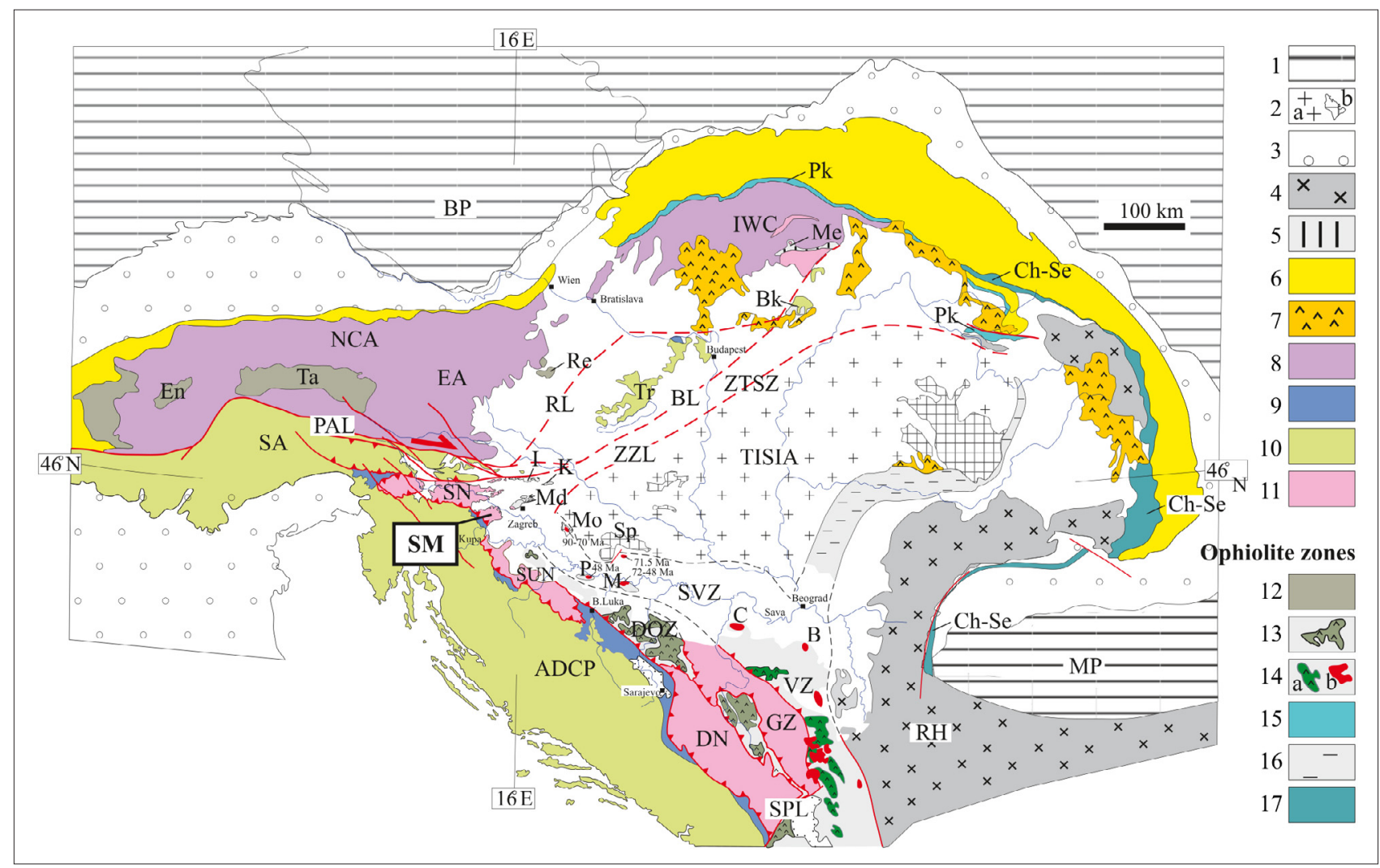

Figure 1: Descriptive map of regional tectonic units and zones in the Alpine-Dinaridic Carpathian orogen and Pannonian basin system (on the basis of data of Aubouin et al., 1970; Csontos et al., 1992; Pamić, 1993; Pamić et al., 1998; Willingshofer, 200o). Abbreviations: Tectonic Units 1) Eurasian foreland (BP Bohemian promontory; MP Moesian platform); 2) Tisia units: a) beneath Neogene cover; b) on the surface; 3) Alpine-Carpathian Molasse belt; 4) Rhodope units (RH); 5) The Meliata units (Me); 6) Alpine-Carpathian flysch belt; 7) Neogene volcanites of Pannonian basin system; 8) Austroalpine units (NCA) Northern Calcareous Alps; EA Eastern Alps, IWC; 9) Slope and basin sequences of eastern margin of ADCP (Bosnian flysch, flysch of Slovenian trough); 10) Units of Southern Alps (SA) and Adriatic-Dinaridic carbonate platform (ADCP); 11) The nappes of Paleozoic-Triassic sequences: GZ Golija zone; DN Durmitor nappe; SUN Sana-Una nappe; SN Sava nappe); 12) Penninic units (En Engadine; Ta Tauern; Re Rechnitz); 13) Units of Dinaridic ophiolite zone (DOZ) with ophiolitic massifs; 14) Units of Varadar (VZ) and Sava-Vardar zone (SVZ) with a) ophiolitic massifs and b) granodioritic intrusives; 15) The zone of Penninic nappes $(\mathrm{Pk})$; 16) Units of Southern Apuseni and Eastern Vardar; 17) Units of Cehla-Severin (Ch-Se); Faults (PAL Periadriatic lineament; RL Raba lineament; BL Balaton lineament; ZZL Zagreb-Zemplin lineament; ZTSZ Zagorje Mid-transdanubian shear zone; SPL Skadar-Peć lineament; Mountains (Bk Bukk Mt.; Tr Transdanubian mountains; I Ivanščica Mt.; K Kalnik Mt.; Md Medvednica Mt; S-M Samobor mountains; Mo Moslavačka gora Mt; Sp Slavonian mountains; P Prosara Mt.; M Motajica Mt.; C Cer Mt., B Bukulja Mt.). Modified after Tomljenović, (2002).

ore deposit might be declared as a prototype of the Permian siderite-polysulphide-barite deposits in the western Tethyan realm.

The aim of this paper is to make detailed petrographic and geochemical analyses on 6 representative samples of the Permian clastic rocks from the St. Barbara ore mine in Rude, in order to determine the provenance, source rock weathering degree and the influence of hydrothermal alterations on investigated source rocks, as well as the geotectonic position of the sedimentation basin.

\subsection{Geology of terrain}

The Samobor Mountains are located in the contact of the three different tectonically influenced areas, that of Alpine, Dinaric, and Pannonian. Its tectonics are very complicated, and the present faults are characterized by different directions, intensity and age. In the structural view, the Samobor Mountains are located in the most western part of the Zagorje-Midtransdanubian zone (ZMTZ) (Tomljenović, 2002), which is bordered by the Periadriatic (PAL), Balaton (BL) and the Zagreb-Zemplin (ZZL) lineament (see Figure 1).

The oldest rocks of the Samobor Mountains are Upper Carboniferous black to gray clay-schists overlain by Permian sandstones that locally contain lenses of black shale and siltstone (Šinkovec, 1971; Šikić et al., 1972). The appearance of conglomerates, limestones, anhydrite, and gypsum in the upper part of the Permian sediment layer indicate the shallowing processes of the sedimentary basin (Herak, 1956). Permian deposits are unconformably overlain by Triassic clastic-carbonate rocks, sandstone, siltstone, shale, limestone, dolomite and chert. Rocks of Jurassic age are poorly represented 
and consist of limestones, subordinate dolomites, limestone breccia, cherts and silicified limestones (Šikić et al., 1972). Cretaceous rocks are characterized by the appearance of greenish greywacke sandstones, shales, radiolarian cherts and flysch (Šikić et al., 1972). Diabase, spilite and subordinate basalt appear within an ophiolite complex whose stratigraphic affinity is not yet clearly defined (Middle Triassic-Upper Jurassic, Lower Cretaceous). Paleocene rocks mainly consist of coloured marls, siltite and subgreywacke sandstones. Neogene sediments are composed of shallow marine clastite, siltite, marl, calcarenite, calcrudite, ridge forming limestone, clays, and clastite with interbedded coal layers. The youngest rocks of this area are Quaternary gravels, sands and clays (Šikić et al., 1972). Ore mineralization in the Rude is located within the Upper Palaeozoic sediments (see Figure 2).

According to Šinkovec (1971), dark gray schists of the Upper Carboniferous prevailed in lower part of the Upper Palaeozoic sediments, and Permian sandstones, containing lenses and layers of black shale, conglomerates, and dolomites constitute its upper part. In the upper part of the sandstone series, there is an $8 \mathrm{~m}$ thick siderite layer, followed upward by a $5 \mathrm{~m}$ thick sandstone layer, which is overlain by the main mass of anhydrite and gypsum. The anhydrite thickness is proven to be at least $45 \mathrm{~m}$. above the anhydrite and gypsum stratum occur either sandstones or Verfenian clastic sediments (Šinkovec, 1971). Ore-rich sulfide veins are situated below the main mass of the siderite layer.

Šinkovec believed that the mineral deposit in Rude correspond to the exhalation-sedimentation type of ore, where the hydrothermal activity took place in three phases and resulted in: a) the formation of the main mass of siderite, part of quartz and pyrite; $b$ ) the formation of the largest part of the pyrite, and c) the formation of vein type mineralization in the scope of which crystallized most sulfide minerals, part of siderite and quartz, and barite in the end. In addition, he thought that iron in the smaller ore bodies that were far away from the siderite body precipitated as hematite. He also pointed out that part of the siderite precipitated during the transition of hydrothermal fluids through the upper parts of still unconsolidated sands. Consequently, the matrix of sandstones situated immediately below the siderite body consists mainly of siderite.

Palinkaš et al. (2010) concluded in their research that the ore deposit in Rude is hosted by Permian non-metamorphosed siliciclastic sediments and evaporites, and consists of stratiform hematite-barite ore, stratabound vein siderite-polysulfide-barite-quartz mineralization and late stage galenite-barite veins. The authors believe that this ore deposit belongs to the SEDEX (sedimentary exhalative) hydrothermal deposit which has been formed by circulation of hydrothermal solutions caused by rift magmatism in the Upper Permian. According to the authors, the ore deposit in Rude represents locus typicus of

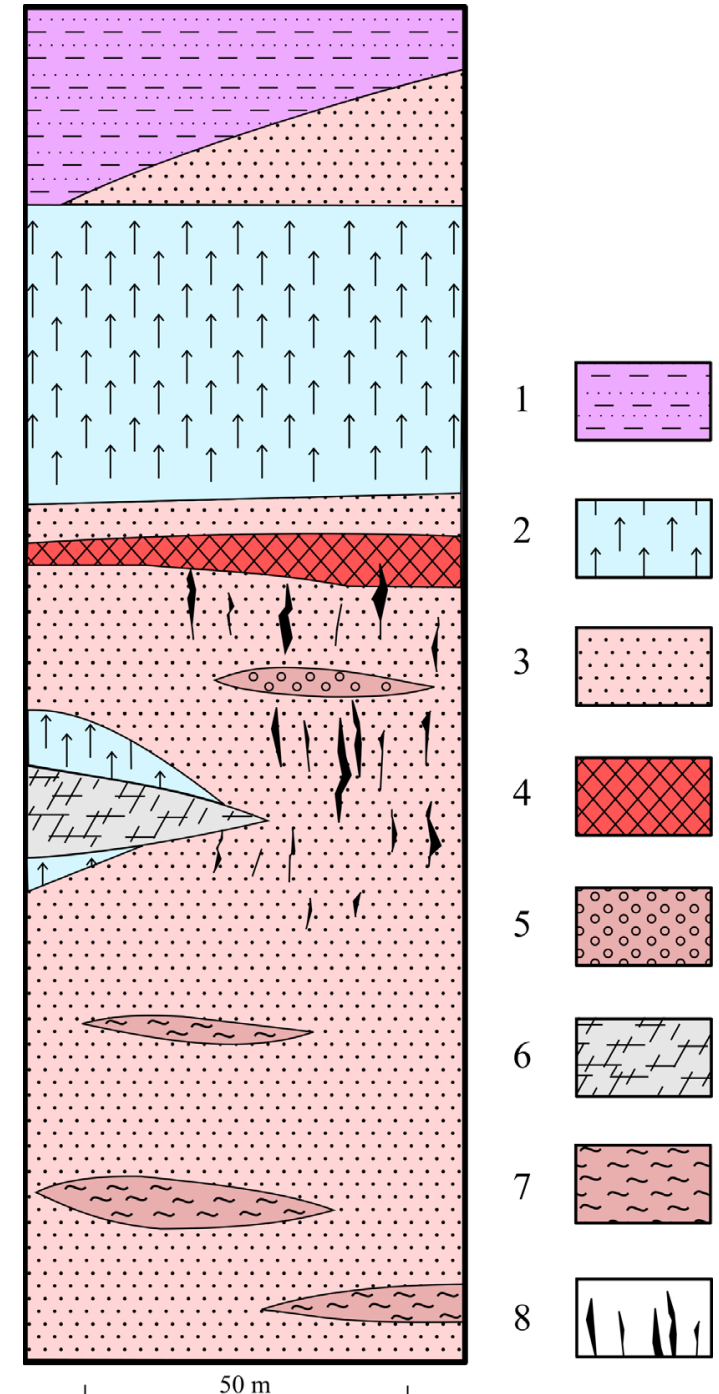

Figure 2: Geologic column of ore deposition area (ك̌inkovec, 1971). 1. Lower Triassic clastic sediments, 2. Anhydrite and Gypsum, 3. Sandstone, 4. Siderite, 5. Conglomerate, 6. Dolomite, 7. Shale, 8 . Ore veins.

the Permian siderite-barite-polysulphide deposits in the western Tethyan realm. However, it should be emphasized that there are no traces of magmatism neither in the mine itself nor in the area of the Samobor Mountains at the time of the formation of ore deposits in Rude.

\section{Analytical methods and sampling}

Detailed petrographic and geochemical analyses were made on the 6 representative samples from different locations in the mine (see Figure 3). Samples RK-1 and RK-2 were collected in the Kokel pit located at $363 \mathrm{~m}$ above sea level. Sample RK-1 was taken near the entrance to the pit, and RK-2 closer to the siderite ore body. Samples RK-3 and RK-5 were sampled in the main excavation chamber of the siderite ore body, and the samples RT-1 and RT-2 were taken in the St. Trojstvo pit located at $350 \mathrm{~m}$ above sea level. Sample RT-1 was col- 


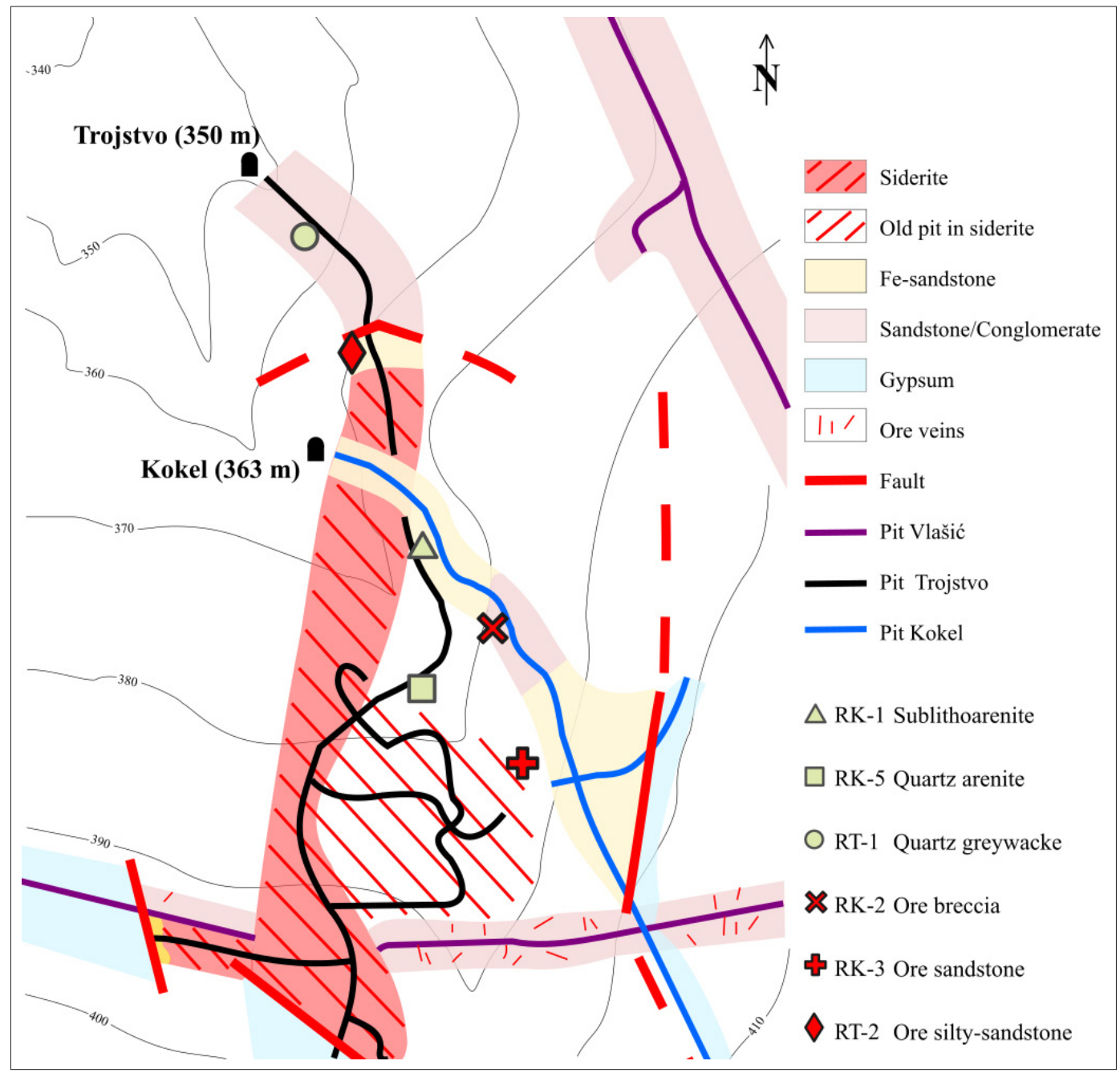

Figure 3: Locations of collected samples. Modified after Šinkovec (1954).

lected at the pit entrance, and sample RT- 2 closer to the former siderite ore body.

The polarization microscope LEITZ LABORLUX 11 POL was used for the petrographic analysis, and the microscopic photographs were taken using the LEICA MICROSYSTEMS 020-522 $101 \mathrm{DM} / \mathrm{LSP}$ polarization microscope in the Institute of Mineralogy, Petrology and Mineral Resources at the Faculty of Mining Geology and Petroleum Engineering, University of Zagreb. All chemical analyses were made in the ACME analytical laboratories Vancouver Ltd. in Canada. Concentrations of the elements were obtained by inductively coupled plasma emission spectrometry (ICP-ES) and trace elements by inductively coupled plasma mass spectrometry (ICP-MS).

\section{Results}

\subsection{Petrographic analysis}

The RK-1 sample consists predominantly of quartz, followed by small amounts of lithic fragments and mus- covite (see Figure 4). Feldspar was not detected. Quartz occurs in the form of monocrystalline and polycrystalline grains having irregular and sutured boundaries which are typical for the quartz of metamorphic origin. All quartz grains show undulose extinction. Some grains also contain fluid inclusions, having linear to sublinear alignment. Lithic fragments are dominated by chert, quartzite, and quartz-muscovite schist. Larger muscovite sheets are bent, and often show undulose extinction. The heavy mineral assemblage is characterized by tourmaline, zircon, and opaque minerals. Mineral grains are well sorted and their dimensions vary from 0.07 to 0.35 $\mathrm{mm}$. The grains are held together by barite and subordinately siderite cement (see Figure 4). Quartz contact with barite cement reveals dissolution effects, and fibrous quartz has also been detected. According to the classification of Pettijohn et al. (1987) the sample is classified as sublithoarenite. The mineral composition indicates a high degree of maturity.

The RK-2 sample contains detrital particles of quartz, lithic fragments, siderite, and mica. Feldspar was not detected. Quartz is present in the form of monocrys- 


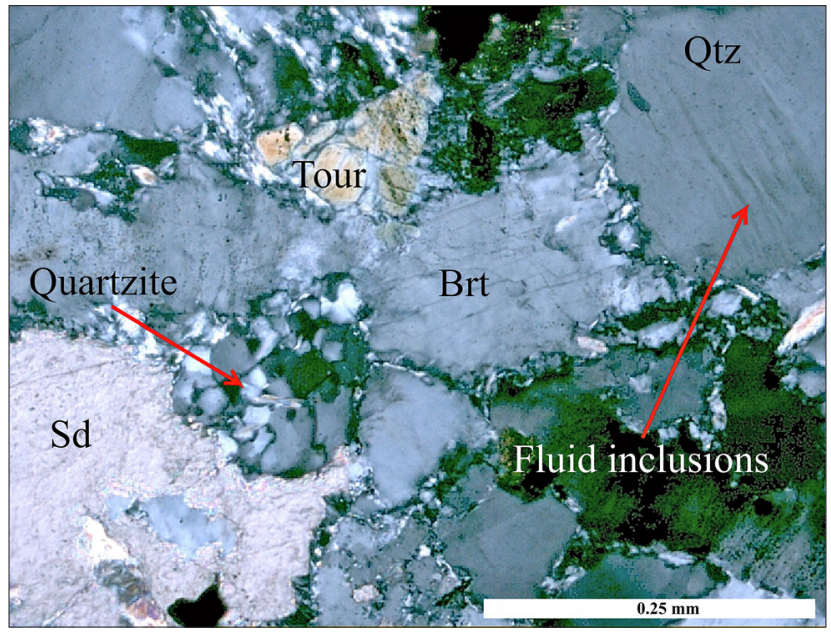

Figure 4: Microscopic photograph of RK-1 sublithoarenite $(+\mathrm{N})$. Fluid inclusions in the quartz have subparallel orientation. Brt = barite, $\mathrm{Qtz}=$ quartz, $\mathrm{Sd}=$ siderite, Tour = tourmaline.

talline and polycrystalline grains with irregular lobate boundaries, showing undulose extinction. Some grains contain fluid inclusions. Siltstone and quartzite are the dominant lithic fragments (see Figure 5), but pelite and sandstone fragments, although rare, are also found. Siderite generally appears as a grain, and rarely as a cement. Mica mineral group is represented by muscovite and biotite. There is no grain support in the structure and the grain size has a wide distribution ranging from 0.04 to $6.0 \mathrm{~mm}$. The detrital components of this clastic rock are cemented by hematite causing the red macroscopic color of the sample. Rarely, hematite also appears as a clast. The rock is classified as an ore breccia.

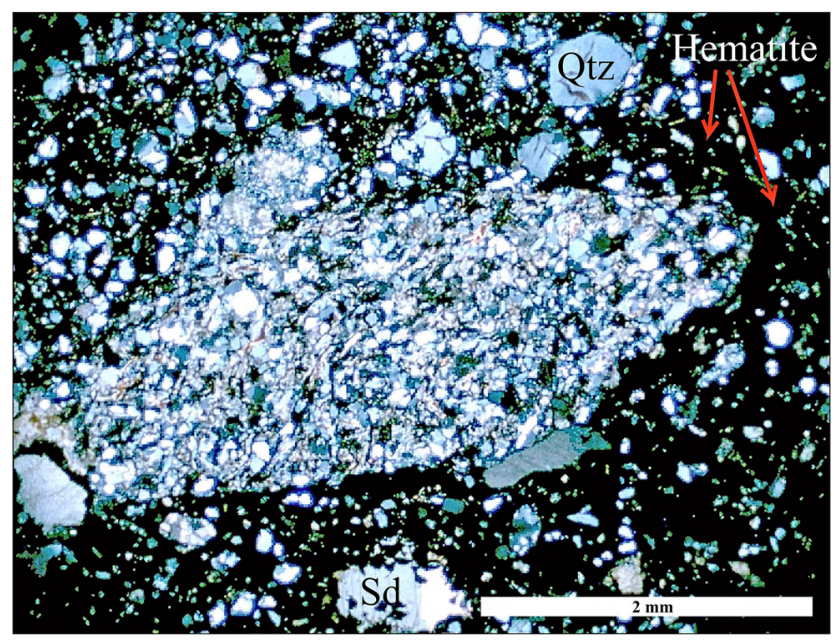

Figure 5: Microscopic photograph of the RK-2 ore breccia $(+\mathrm{N})$. A fragment of siltite in hematite cement. Hem = hematite, $\mathrm{Qtz}=$ quartz, Sd = siderite.

In the RK-3 sample only rare monocrystalline and polycrystalline angular clasts of quartz can be clearly detected, usually in the range 0.05 to $1.25 \mathrm{~mm}$. In the close vicinity of rock fissures, quartz also occur in association with barite, pointing to its possible chemical origin. There is no support between clasts and they are bonded with cement, which is volumetrically dominant in this sample. The cement is made of hematite, siderite, and barite. In some places, colloidal band structure of siderite cement is visible (see Figure 6). Due to the intense hydrothermal alteration, the sandstone is not classified according to classification of Pettijohn et al. (1987), but is simply named as an ore sandstone.

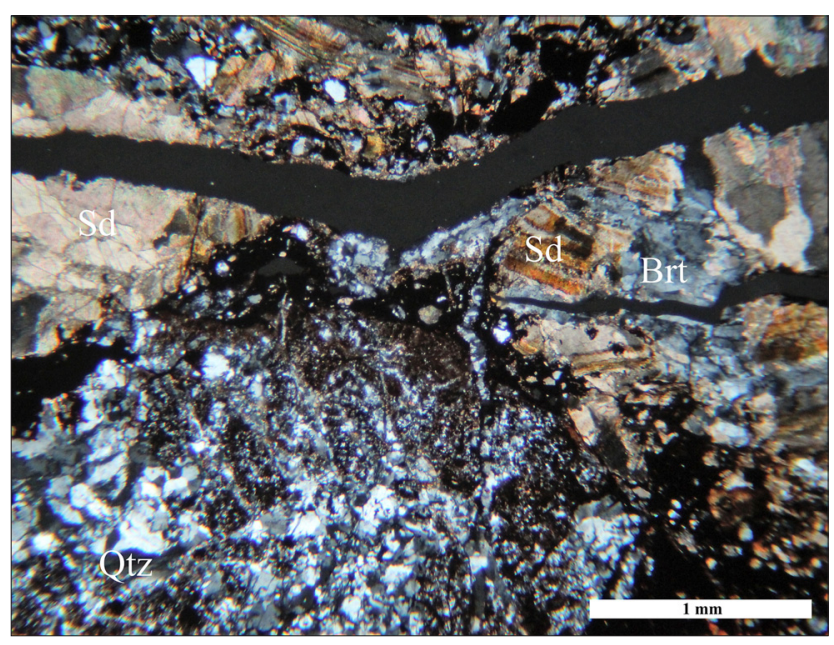

Figure 6: Microscopic photograph of $\mathrm{RK}_{-3}$ ore sandstone $(+N)$. Colloidal siderite band and barite found in the veins crosscutting the sandstone. Brt = barite, $\mathrm{Sd}=$ siderite, $\mathrm{Qtz}=$ quartz

Sample RK-5 mainly contains monocrystalline and polycrystalline quartz grains and a smaller amount of lithic fragments and muscovite (see Figure 7). Feldspar was not detected. Quartz grains show undulose extinction. The boundaries between the polycrystalline grains are irregular, mosaic, with structures that indicate the pressure dissolution or recrystallization by the mechanism of either the grain boundary migration or the domain rotation. Some grains also contain fluid inclusions. Detrital quartz grain shows untypical narrow, densely subparallel arranged deformation lamellaes (see Figure 8). They have been considered as possible shock metamorphic phenomena (planar deformation features PDFs) related to meteorite impact at the Permian-Triassic border (Palinkaš et al., 2010), but such lamellaes in quartz could be also tectonically induced (Vernooij and Langenhorst, 2005). The only lithic fragment is quartzite. The grain dimensions vary from 0.02 to $2.00 \mathrm{~mm}$. Clasts are embedded in fine grained quartz material without grain support. In some places rare quartz-sericite matrix occurs, which is most likely a product of the clay matrix recrystallization. It is possible that a considerable part of the finely grained quartz was formed chemically. Siderite cement appears in a negligible amount. According to the classification of Pettijohn et al. (1987), the sample was classified as quartz arenite. Due to its mineral 


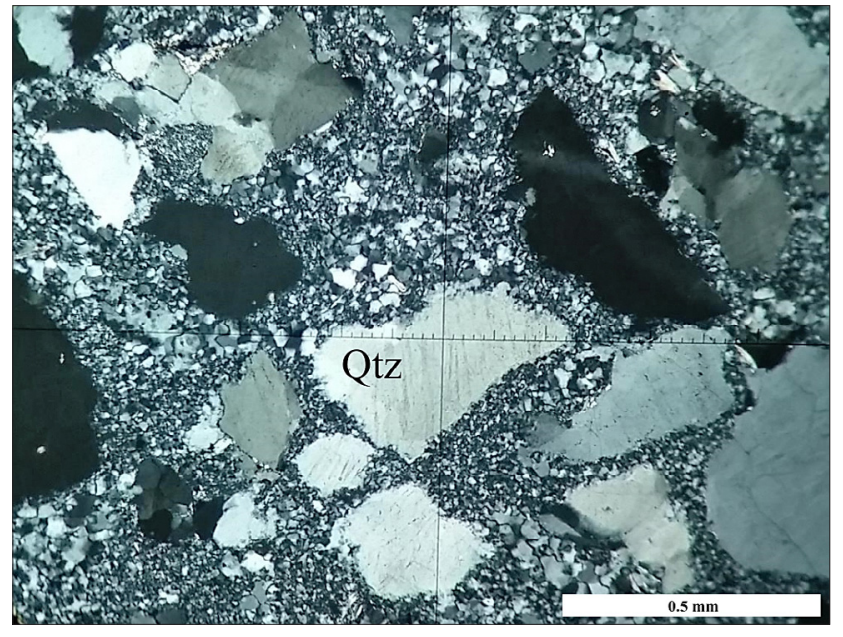

Figure 7: Microscopic photograph of the RK-5 quartz arenite $(+\mathrm{N})$. Poorly sorted quartz clasts in the finely grained quartz material, which could be formed chemically. Qtz = quartz.

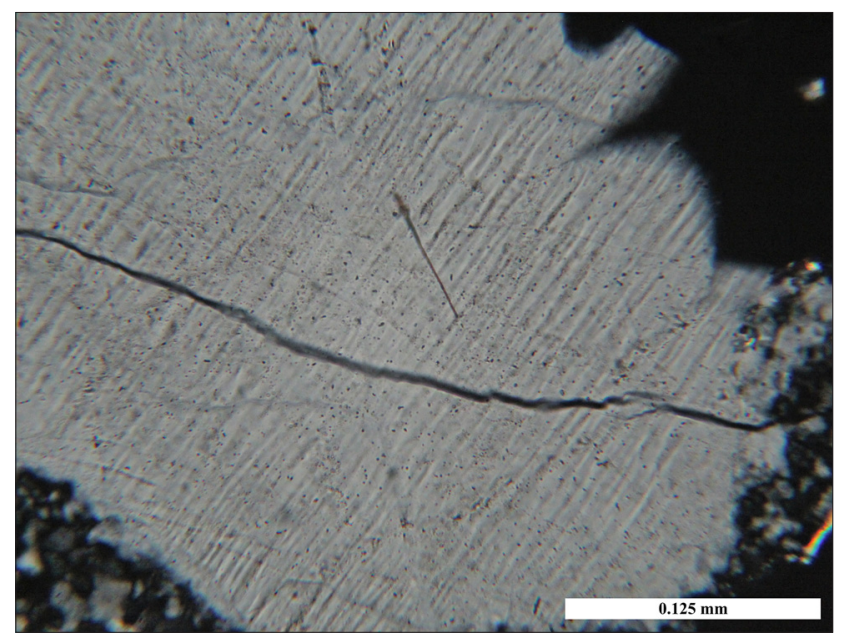

Figure 8: Microscopic photograph of densely subparallel arranged deformation lamellaes (PDFs?) decorated by fluid and mineral inclusions in quartz clast of the RK-5 quartz arenite $(+\mathrm{N})$.

composition, sandstone indicates a high degree of maturity, it is still characterized by very poorly sorted angular clasts, indicating short transport.

The RT-1 sample consists dominantly of monocrystalline and polycrystalline quartz grains and small amount of lithic fragments and micas (see Figure 9). Feldspar was not detected. Quartz grain, whose dimensions vary from 0.05 to $1.25 \mathrm{~mm}$, have undulose extinction. Many of them contain untypical narrow, densely, subparallel arranged deformation lamellaes most often decorated by fluid or mineral inclusions. Rare lithic fragments are represented by quartzite and quartz-muscovite schist. Muscovite is the dominant phase in mica minerals and shows undulose extinction or is bent. Heavy mineral assemblage consists of tourmaline, zircon and opaque minerals. The clasts generally have grain support and the primary clay matrix is recrystallized into quartzsericite matrix. In some places, there is a siderite cement.

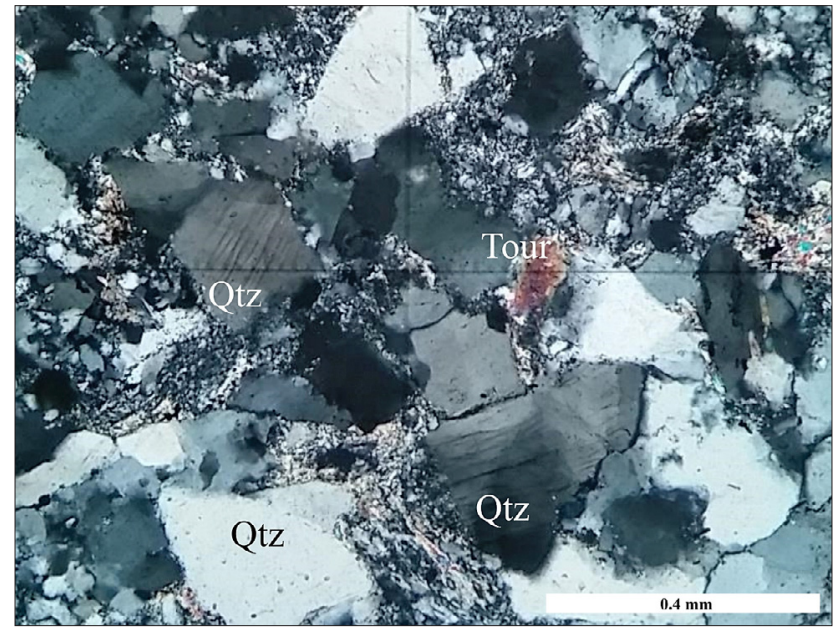

Figure 9: Microscopic photograph of RT-1 quartz greywacke $(+\mathrm{N})$. Well sorted clasts with grain support are held together by a quartz-sericite matrix and, in some cases, by the siderite cement. Qtz = Quartz, Tour = tourmaline.

According to the classification of Pettijohn et al. (1987) the sample was classified as quartz greywacke. The sandstone is characterized by relatively good sorting of poorly rounded quartz-dominated clasts.

The RT-2 sample contains monocrystalline quartz grains that prevail over polycrystalline quartz and subordinate muscovite (see Figure 10). Lithic fragments and feldspar were not observed. Quartz has undulose extinction and rarely contains untypical narrow, densely subparallel arranged deformation lamellaes and fluid inclusions. Most of clasts are without grain support and are held together by siderite cement that has been locally shifted to hematite. The larger siderite grains show deformations in the form of undulose extinction. In the small veinlets, crosscutting the sample, quartz, siderite and euhedral pyrite have crystallized. The size of clasts varies from 0.05 to $0.50 \mathrm{~mm}$. Considering that the sam-

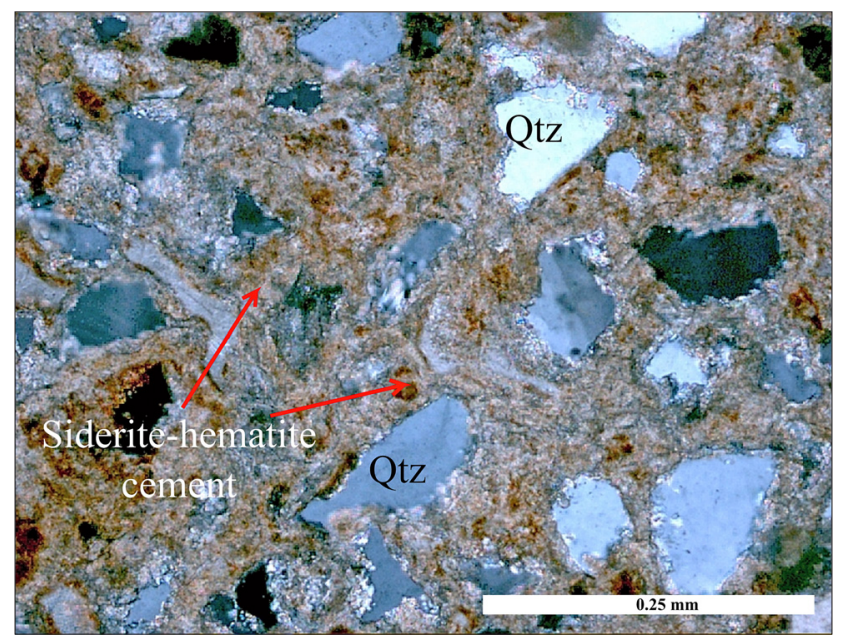

Figure 10: Microscopic photograph of RT-2 ore silt sandstone $(+\mathrm{N})$. The sandstone is cemented by siderite, which oxidizes into hematite cement. Qtz = quartz. 
ple consists of sand, as well as silt particles this rock has been named as ore silty sandstone, without using a classical classification of Pettijohn et al. (1987). Poorly rounded and poorly sorted quartz grains indicate a short transport distance.

\subsection{Chemical analysis}

Chemical analysis of the major element oxides, expressed in weight percentages, are shown in Table 1. Compared to the average composition of the upper continental crust (UCC), determined by Taylor and McLennan (1985), major element oxides in most of the studied samples are depleted. Still, $\mathrm{SiO}_{2}$ concentrations are an exception in RK-5 quartz arenite $(96.35 \%)$ and RT-1 quartz greywacke $(80.67 \%)$. As can be expected, in the vicinity of $\mathrm{Fe}$-ore deposits, $\mathrm{Fe}_{2} \mathrm{O}_{3}$ concentrations were increased in relation to the upper continental crust (UCC) in RK-1 sublithoarenite (6.31\%), RK-2 ore breccia (38.12\%), RK-3 ore sandstone (48.25\%) and RT-2 ore silty sandstone $(38.54 \%)$. The content of $\mathrm{MgO}$ ranges from 0.10 to $4.26 \%$, and $\mathrm{MnO}$ from 0.02 to $1.39 \%$. There is a clear positive correlation observed between the amount of siderite and $\mathrm{MgO}$ and $\mathrm{MnO}$ concentrations in the samples, which can be explained by the substitution of $\mathrm{Mg}^{2+}$ and $\mathrm{Mn}^{2+}$ for $\mathrm{Fe}^{2+}$ in the siderite crystalline structure. Very low concentrations of $\mathrm{CaO}(0.01$ $0.60 \%)$ and $\mathrm{Na}_{2} \mathrm{O}(0.01$ to $0.10 \%)$ in all samples are consistent with petrographic analysis in which neither plagioclase nor calcite was observed. A strong positive correlation show $\mathrm{Al}_{2} \mathrm{O}_{3}(0.87-8.01 \%), \mathrm{TiO}_{2}(0.08-0.50 \%)$ and $\mathrm{K}_{2} \mathrm{O}(0.05-1.72 \%)$ concentrations, pointing to the association of these oxides in phyllosilicates. The highest amounts of $\mathrm{Al}_{2} \mathrm{O}_{3}, \mathrm{TiO}_{2}$, and $\mathrm{K}_{2} \mathrm{O}$ are found in RT-1 quartz greywacke, the sample in which, as petrographic analysis revealed, the micas are the most widespread.

Table 2 shows trace element data expressed in ppm. It is evident that analysed sediments show trace element concentrations, mostly lower than the average composition of the upper crust (see Figures 11 and 12). The exceptions are Cs, which has slightly elevated concentrations in RK-2 ore breccia (27.0 ppm) and RT-1 quartz greywacke (5.6 ppm), Ba with elevated concentrations in all samples except RK-5 quartz arenite (337.0 ppm), Sr elevated in RK-1 sublithoarenite and RK-3 ore sandstone (5810.0 and $4280.0 \mathrm{ppm}$ ), and Ta slightly elevated in RK-1 sublithoarenite (6.3 ppm). Slightly elevated concentrations of Cs in the RK-2 ore breccia and RT-1 quartz greywacke can be linked to the present phyllosilicates. Elevated concentrations of $\mathrm{Ba}$ and $\mathrm{Sr}$ are positively correlated with the occurrence and amount of barite in the samples. Increased concentration of Ta in the RK-1 sublithoarenite could be related to mineral zircon, tourmaline and/or phyllosilicates present in this sample in a larger quantity than in the others.

Rare earth element concentrations are shown in Table 3 and normalized to chondrite (Sun and Medonough, 1989) in Figures 13 and 14. The enrichment of light REEs in relation to the heavy REEs is visible in all samples with $(\mathrm{La} / \mathrm{Yb})_{\mathrm{N}}$ ratios varying between 1.84 and 11.78. Two groups of samples are clearly distinguished. RK-1 sublithoarenite, RK-3 ore sandstone, and RT-2 ore silty sand-

Table 1: Chemical analyses of main elements (weight \%)

\begin{tabular}{|c|c|c|c|c|c|c|c|}
\hline Sample & RK-1 & RK-2 & RK-3 & RK-5 & RT-1 & RT-2 & UCC \\
\hline & $\begin{array}{l}\text { Sublitho- } \\
\text { arenite }\end{array}$ & Ore breccia & Ore sandstone & Quartz arenite & $\begin{array}{c}\text { Quartz } \\
\text { greywacke }\end{array}$ & $\begin{array}{l}\text { Ore silty- } \\
\text { sandstone }\end{array}$ & $\begin{array}{c}\text { Taylor and } \\
\text { McLennon } \\
\text { (1985) }\end{array}$ \\
\hline $\mathrm{SiO}_{2}$ & 38.39 & 45.87 & 28.10 & 96.35 & 80.67 & 31.41 & 66.00 \\
\hline $\mathrm{Al}_{2} \mathrm{O}_{3}$ & 2.63 & 6.70 & 1.05 & 1.22 & 8.01 & 0.87 & 15.20 \\
\hline $\mathrm{Fe}_{2} \mathrm{O}_{3}$ & 6.31 & 38.12 & 48.25 & 0.70 & 3.87 & 38.54 & 5.03 \\
\hline MgO & 0.79 & 0.87 & 2.19 & 0.10 & 0.62 & 4.26 & 2.20 \\
\hline $\mathrm{CaO}$ & 0.06 & 0.20 & 0.42 & 0.01 & 0.09 & 0.60 & 4.20 \\
\hline $\mathrm{Na}_{2} \mathrm{O}$ & 0.10 & 0.10 & 0.01 & 0.02 & 0.10 & 0.02 & 3.90 \\
\hline $\mathrm{K}_{2} \mathrm{O}$ & 0.54 & 1.57 & 0.05 & 0.25 & 1.72 & 0.18 & 3.40 \\
\hline $\mathrm{TiO}_{2}$ & 0.15 & 0.48 & 0.15 & 0.08 & 0.50 & 0.22 & 0.68 \\
\hline $\mathbf{P}_{2} \mathrm{O}_{5}$ & 0.04 & 0.03 & 0.04 & $<0.01$ & 0.05 & 0.02 & 0.15 \\
\hline MnO & 0.28 & 0.15 & 0.66 & 0.02 & 0.14 & 1.39 & 0.08 \\
\hline $\mathrm{Cr}_{2} \mathrm{O}_{3}$ & 0.01 & 0.01 & 0.00 & $<0.00$ & 0.00 & 0.00 & \\
\hline $\mathrm{Na}_{2} \mathrm{O} / \mathrm{K}_{2} \mathrm{O}$ & 0.19 & 0.06 & 0.20 & 0.08 & 0.06 & 0.11 & \\
\hline $\mathrm{K}_{2} \mathrm{O} / \mathrm{Na}_{2} \mathrm{O}$ & 5.40 & 15.70 & 5.00 & 12.50 & 17.20 & 9.00 & \\
\hline $\mathrm{Fe}_{2} \mathrm{O}_{3} / \mathrm{MgO}$ & 7.99 & 43.82 & 22.03 & 7.00 & 6.24 & 9.05 & \\
\hline $\mathrm{Al}_{2} \mathrm{O}_{3} / \mathrm{SiO}_{2}$ & 0.07 & 0.15 & 0.04 & 0.01 & 0.10 & 0.03 & \\
\hline LOI & 4.50 & 5.60 & 10.60 & 1.20 & 4.00 & 22.10 & \\
\hline$\sum$ & 53.83 & 99.70 & 91.55 & 99.96 & 99.81 & 99.57 & \\
\hline CIA & 79.00 & 78.20 & 68.60 & 81.30 & 80.70 & 52.10 & \\
\hline
\end{tabular}


Table 2: Trace element concentrations (ppm).

\begin{tabular}{|l|l|l|l|l|l|l|l|}
\hline Sample & RK-1 & RK-2 & RK-3 & RK-5 & RT-1 & RT-2 & UCC \\
\hline & $\begin{array}{l}\text { Sublitho- } \\
\text { arenite }\end{array}$ & Ore breccia & Ore sandstone & Quartzarenite & $\begin{array}{l}\text { Quartz } \\
\text { greywacke }\end{array}$ & $\begin{array}{l}\text { Ore silty } \\
\text { sandstone }\end{array}$ & $\begin{array}{l}\text { McLennon } \\
(2001)\end{array}$ \\
\hline $\mathbf{B a}$ & $>50000.0$ & 1510.0 & $>50000.0$ & 337.0 & 1115.0 & 2043.0 & 550.0 \\
$\mathbf{B e}$ & $<1.0$ & 2.0 & 2.0 & $<1.0$ & 2.0 & 1.0 & 3.0 \\
$\mathbf{C o}$ & 19.6 & 1.1 & 1.7 & $<0.2$ & 10.7 & 6.0 & 17 \\
$\mathbf{C s}$ & 2.4 & 27.0 & 1.5 & 1.6 & 5.6 & 0.8 & 4.6 \\
$\mathbf{G a}$ & 2.5 & 12.4 & 1.8 & 4.3 & 10.3 & 3.7 & 17 \\
$\mathbf{H f}$ & 4.0 & 4.7 & 2.4 & 0.7 & 4.3 & 2.6 & 5.8 \\
$\mathbf{N b}$ & 3.0 & 7.5 & 2.7 & 1.3 & 7.1 & 3.3 & 12.0 \\
$\mathbf{R b}$ & 23.6 & 82.3 & 2.5 & 11.0 & 64.9 & 7.0 & 112.0 \\
$\mathbf{S n}$ & $<1.0$ & 3.0 & $<1.0$ & $<1.0$ & 2.0 & $<1.0$ & 5.5 \\
$\mathbf{S r}$ & 5810.0 & 56.7 & 4280.0 & 11.5 & 127.8 & 82.1 & 350.0 \\
$\mathbf{T a}$ & 6.3 & 0.6 & 1.0 & 0.1 & 0.7 & 0.3 & 1.0 \\
$\mathbf{S c}$ & 1 & 6 & 1 & $<1$ & 5 & 2 & 13.6 \\
$\mathbf{T h}$ & 2.4 & 7.7 & 1.6 & 1.4 & 7.8 & 3.0 & 10.7 \\
$\mathbf{U}$ & 0.9 & 2.2 & 0.5 & 0.5 & 1.7 & 0.7 & 2.8 \\
$\mathbf{V}$ & 13.0 & 72.0 & 25.0 & $<8.0$ & 29.0 & 21.0 & 107 \\
$\mathbf{W}$ & 2.1 & 2.3 & 7.7 & 0.6 & 1.3 & 0.7 & 2.0 \\
$\mathbf{Z r}$ & 77.1 & 160.4 & 67.8 & 21.1 & 142.1 & 94.0 & 190.0 \\
$\mathbf{Y}$ & 5.5 & 14.8 & 5.0 & 3.1 & 10.8 & 6.2 & 22.0 \\
\hline $\mathbf{M o}$ & 0.3 & 0.2 & 0.1 & 0.1 & $<0.1$ & 0.2 & 1.5 \\
$\mathbf{C u}$ & 6.0 & 0.7 & 0.4 & 0.8 & 6.5 & 21.8 & 25 \\
$\mathbf{P b}$ & 22.0 & 54.3 & 17.4 & 0.4 & 9.1 & 8.0 & 17.0 \\
$\mathbf{Z n}$ & 4.0 & 21.0 & 66.0 & $<1.0$ & 5.0 & 488.0 & 71 \\
$\mathbf{N i}$ & 7.1 & 2.6 & 7.6 & 0.3 & 18.6 & 9.8 & 44 \\
$\mathbf{A s}$ & 103.5 & 4.7 & 6.5 & $<0.5$ & 17.6 & 9.7 & 1.5 \\
$\mathbf{C d}$ & $<0.1$ & $<0.1$ & $<0.1$ & $<0.1$ & $<0.1$ & 0.1 & 98 \\
$\mathbf{S b}$ & 5.1 & 34.6 & 16.1 & $<0.1$ & 0.3 & 1.8 & 0.2 \\
$\mathbf{B i}$ & 0.2 & $<0.1$ & $<0.1$ & $<0.1$ & $<0.1$ & $<0.1$ & 127 \\
$\mathbf{A g}$ & 0.9 & $<0.1$ & $<0.1$ & $<0.1$ & 0.3 & $<0.1$ & 50 \\
$\mathbf{A u}(\mathbf{p p b})$ & 1.1 & $<0.5$ & $<0.5$ & $<0.5$ & $<0.5$ & $<0.5$ & \\
$\mathbf{H g}$ & 1.4 & 0.3 & 0.4 & 0.4 & 3.1 & 4.1 & \\
$\mathbf{T r}$ & $<0.1$ & $<0.1$ & $<0.1$ & $<0.1$ & 0.2 & $<0.1$ & 750 \\
$\mathbf{S e}$ & $<0.5$ & $<0.5$ & $<0.5$ & $<0.5$ & $<0.5$ & $<0.5$ & 50 \\
\hline
\end{tabular}

stone show positive Eu-anomalies (2.3; 3.8 and 4.5) and lower concentrations of light rare earths (see Figure 13), while RK-2 ore breccia, RK-5 quartz arenite, and RT-1 quartz graywacke (see Figure 14) show a negative Euanomaly $(0.1,0.6$ and 0.4$)$ and are characterized by a higher total REE (63.51, 23.79 and 98.51). Eu anomaly was calculated as $\mathrm{Eu} / \mathrm{Eu}^{*}=\mathrm{Eu}_{\mathrm{N}} / \sqrt{ }\left[\left(\mathrm{Sm}_{\mathrm{N}}\right) *\left(\mathrm{Gd}_{\mathrm{N}}\right)\right]$.

\section{Discussion}

\subsection{Rock classification}

The chemical rock classification of studied samples based on the logarithmic ratios of the major elements $\mathrm{Fe}_{2} \mathrm{O}_{3} / \mathrm{K}_{2} \mathrm{O}$ and $\mathrm{SiO}_{2} / \mathrm{Al}_{2} \mathrm{O}_{3}$ (Herron, 1998), partly correlates with petrographic analyses (see Figure 15). The samples RT-1 and RK-5 petrographically determined as quartz greywacke and quartz arenite are projected into the fields of lithic and quartz arenites, respectively. The other studied samples are plotted into the area of iron sandstone. Petrographic analyses have revealed that some samples after deposition were exposed to hydrothermal fluids rich in $\mathrm{Fe}, \mathrm{Ba}$ and $\mathrm{Si}$ and have undergone significant chemical changes. This explains the partial incompatibility of petrographic and chemical classifications.

\subsection{Provenance}

The lack of feldspar, the rare presence of lithic fragments, and the dominant presence of quartz point to the felsic or quartz sedimentary source rock. Quartz in all samples has undulose extinction and, moreover, shows deformations and contains many inclusions, so a volcanic origin of the rocks is unlikely. It is more likely that 


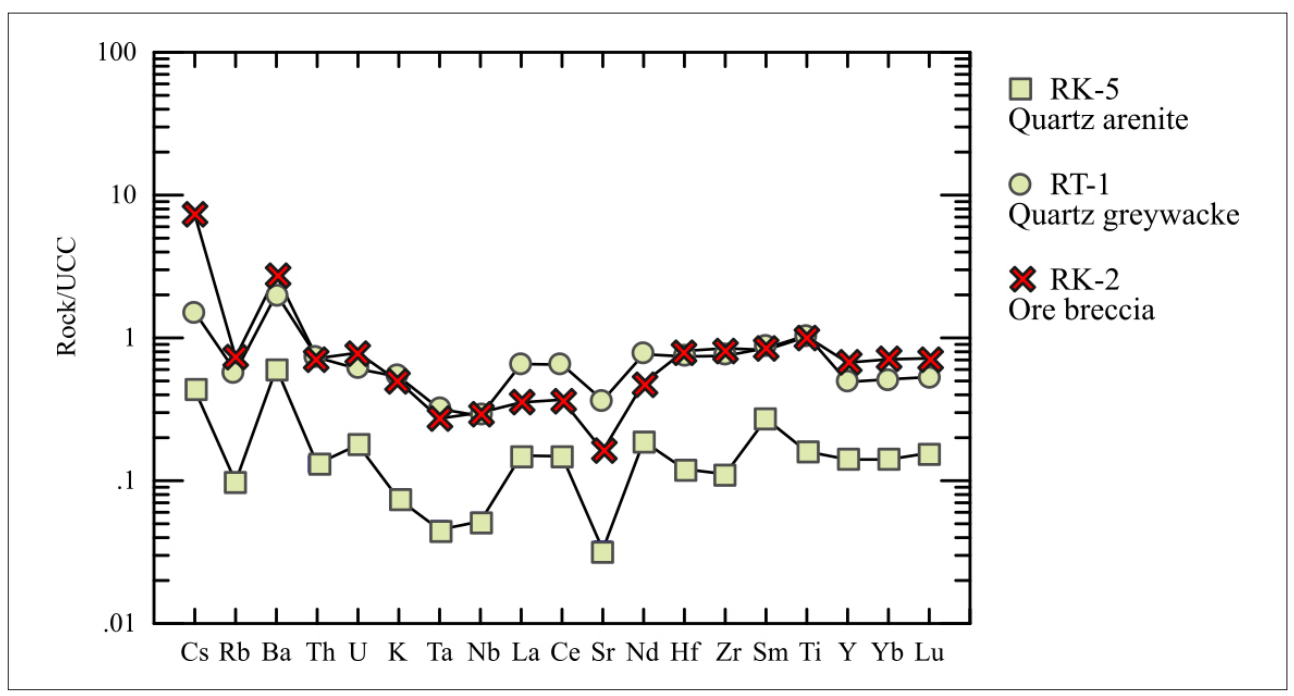

Figure 11: Trace element concentrations of samples RK-2, RK-5 and RT-1 normalised on UCC

(Taylor and McLennan, 1985)

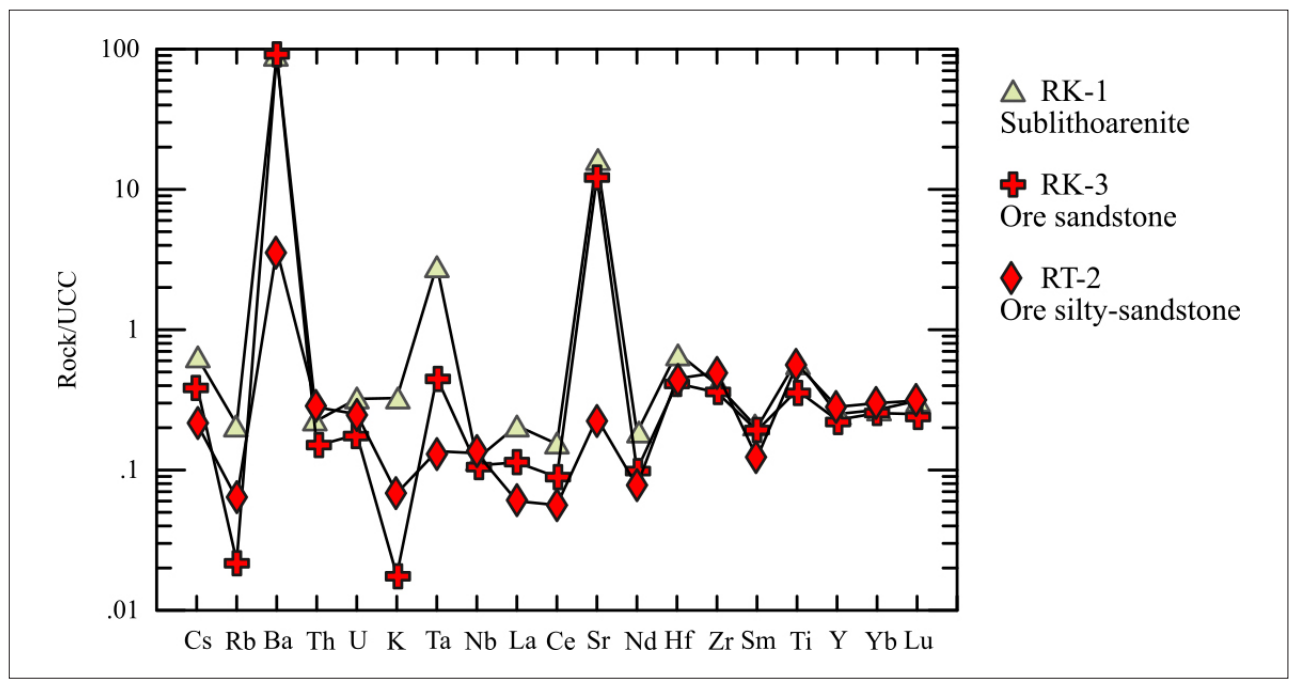

Figure 12: Trace element concentrations of samples RK-1, RK-3 and RT-2 normalised on UCC

(Taylor and McLennan, 1985)

the studied sandstones were formed by the decomposition of acid intrusive or even metamorphic rocks, which can be concluded from a very common occurrence of polycrystalline quartz grains. In the discrimination diagram (Roser and Korsch, 1988) in Figure 16, the least hydrothermal modified RT-1 quartz greywacke, RK-5 quartz arenite and the RK-1 sublithoarenite are projected into the quartz sedimentary region. Other samples are located in a field of mafic igneous origin, which, of course, is not a real picture, but rather the result of the influence of iron-rich hydrothermal fluids that have secondarily modified sandstone. Due to the fact that the discriminant variables D1 and D2 are based on contents of major oxides $\left(\mathrm{Al}_{2} \mathrm{O}_{3}, \mathrm{TiO}_{2}, \mathrm{Fe}_{2} \mathrm{O}_{3}, \mathrm{MgO}, \mathrm{CaO}, \mathrm{Na}_{2} \mathrm{O}\right.$ and $\mathrm{K}_{2} \mathrm{O}$ ), which are mobile during weathering and alteration, the ratios of certain trace elements with lower mobility characteristics are used additionally for determina- tion of source rocks. It is well known that the highly incompatible nature of REEs, Th, $\mathrm{Zr}$ and Hf during the igneous melting and fractionation processes causes the enrichment of these elements in felsic rocks. More compatible elements such as $\mathrm{Sc}, \mathrm{Co}, \mathrm{Cr}$ and $\mathrm{Ni}$ are typical for mafic and ultramafic rock. Therefore, $\mathrm{La} / \mathrm{Sc}, \mathrm{Th} / \mathrm{Sc}, \mathrm{La} /$ $\mathrm{Co}, \mathrm{Th} / \mathrm{Co}, \mathrm{Cr} / \mathrm{Th}$ and $\mathrm{Th} / \mathrm{U}$ ratios of siliciclastic rocks are very good provenance indicators (Cullers and Berendsen, 1998). An assumption of felsic source of studied rocks is supported by the analyzed values of these ratios in Table 4. For instance, $\mathrm{La} / \mathrm{Sc}$ and $\mathrm{Th} / \mathrm{Sc}$ ratios of all investigated samples are in range between 0.9-6.2 and 1.3-2.4, respectively, which corresponds to felsic rocks. Additionally, in all samples except for strongly hydrothermally altered RK-2 ore breccia and RT-2 ore silty sandstone, $\mathrm{La} / \mathrm{Sc}$ ratios are higher than those of the average upper continental crust determined by McLen- 
Table 3: Rare earth element concentrations (ppm).

\begin{tabular}{|c|c|c|c|c|c|c|c|}
\hline Sample & RK-1 & RK-2 & RK-3 & RK-5 & RT-1 & RT-2 & UCC \\
\hline & $\begin{array}{l}\text { Sublitho- } \\
\text { arenite }\end{array}$ & Ore breccia & Ore sandstone & Quartz arenite & $\begin{array}{c}\text { Quartz } \\
\text { greywacke }\end{array}$ & $\begin{array}{l}\text { Ore silty } \\
\text { sandstone }\end{array}$ & $\begin{array}{c}\text { McLennon } \\
\text { (2001) }\end{array}$ \\
\hline La & 6.20 & 10.60 & 3.40 & 4.50 & 19.70 & 1.80 & 30.00 \\
\hline $\mathrm{Ce}$ & 9.80 & 23.60 & 5.70 & 9.50 & 41.60 & 3.60 & 64.00 \\
\hline Pr & 1.18 & 2.86 & 0.70 & 1.19 & 5.07 & 0.46 & 7.10 \\
\hline Nd & 4.80 & 12.60 & 2.60 & 4.90 & 20.00 & 2.00 & 26.0 \\
\hline Sm & 0.90 & 3.71 & 0.86 & 1.22 & 3.82 & 0.55 & 4.50 \\
\hline Eu & 1.09 & 0.08 & 1.37 & 0.17 & 0.38 & 1.10 & 0.88 \\
\hline Gd & 2.24 & 2.95 & 1.42 & 0.73 & 2.75 & 1.01 & 3.80 \\
\hline $\mathbf{T b}$ & 0.23 & 0.48 & 0.23 & 0.10 & 0.38 & 0.18 & 0.64 \\
\hline Dy & 0.27 & 2.55 & 0.87 & 0.65 & 1.90 & 1.00 & 3.50 \\
\hline Ho & 0.31 & 0.55 & 0.21 & 0.12 & 0.37 & 0.24 & 0.80 \\
\hline $\mathbf{E r}$ & 0.70 & 1.51 & 0.59 & 0.29 & 1.07 & 0.65 & 2.30 \\
\hline Tm & 0.10 & 0.23 & 0.09 & 0.06 & 0.17 & 0.10 & 0.33 \\
\hline $\mathbf{Y b}$ & 0.59 & 1.56 & 0.56 & 0.31 & 1.13 & 0.66 & 2.20 \\
\hline Lu & 0.10 & 0.23 & 0.08 & 0.05 & 0.17 & 0.10 & 0.32 \\
\hline$\sum$ REE & 28.51 & 63.51 & 18.68 & 23.79 & 98.51 & 13.45 & 146.37 \\
\hline $\mathbf{E u} / \mathbf{E u}$ * & 2.30 & 0.10 & 3.80 & 0.60 & 0.40 & 4.50 & $0.40-0.94$ \\
\hline$(\mathrm{La} / \mathrm{Yb})_{\mathrm{N}}$ & 7.10 & 4.59 & 4.10 & 9.81 & 11.78 & 1.84 & \\
\hline$(\mathrm{La} / \mathrm{Sm})_{\mathrm{N}}$ & 4.34 & 1.80 & 2.49 & 2.32 & 3.25 & 2.06 & \\
\hline$(\mathbf{G d} / \mathbf{Y b})_{\mathrm{v}}$ & 3.08 & 1.53 & 2.06 & 1.91 & 1.97 & 1.24 & \\
\hline
\end{tabular}

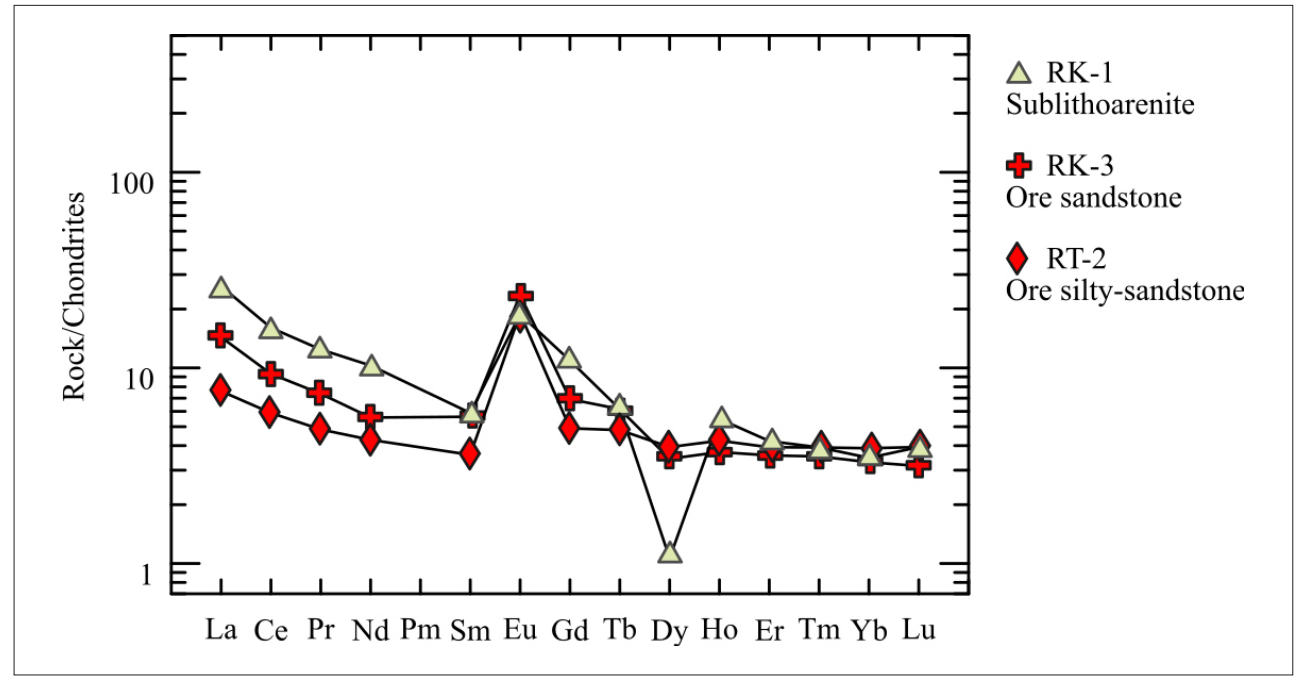

Figure 13: The chondrite normalized (Sun and McDonough, 1989) REE patterns of samples RK-1, RK-3 and RT-2

nan (2001). The $\mathrm{Th} / \mathrm{Sc}$ ratios are in all studied samples higher than in the average upper continental crust.

McLennan et al. (1993) showed that in most upper crustal rocks the $\mathrm{Th} / \mathrm{U}$ ratio usually varies between 3.5 and 4.0. The $\mathrm{Th} / \mathrm{U}$ ratio in sedimentary rocks higher than 4.0 pointing to strong weathering in source areas or sediment recycling, due to the fact that weathering and recycling result in loss of U (Rahman and Suzuki, 2007). $\mathrm{Th} / \mathrm{U}$ ratios greater than or equal to 4 indicates the acidic parent rocks and less than 4 basic source (Rahman and Suzuki, 2007). In the RT-1 quartz greywacke and RT-2 ore silty-sandstone samples $\mathrm{Th} / \mathrm{U}$ ratio exceeds 4 (4.6 and 4.3), which indicates an acid source while the RK-1 sublithoarenite, RK 2 ore breccia, RK-3 ore sandstone and RK-5 quartz arenite samples have values less than 4 indicating a basic source. The REE analysis separates the samples into two groups. Samples of RK-2 ore breccia, RK-5 quartz arenite, and RT-1 quartz greywacke have up to 90 times higher REE concentrations compared to chondrites and a pronounced negative $\mathrm{Eu}$ anomaly. Such a trend is typical for sedimentary rocks and in general represents the composition of an upper 


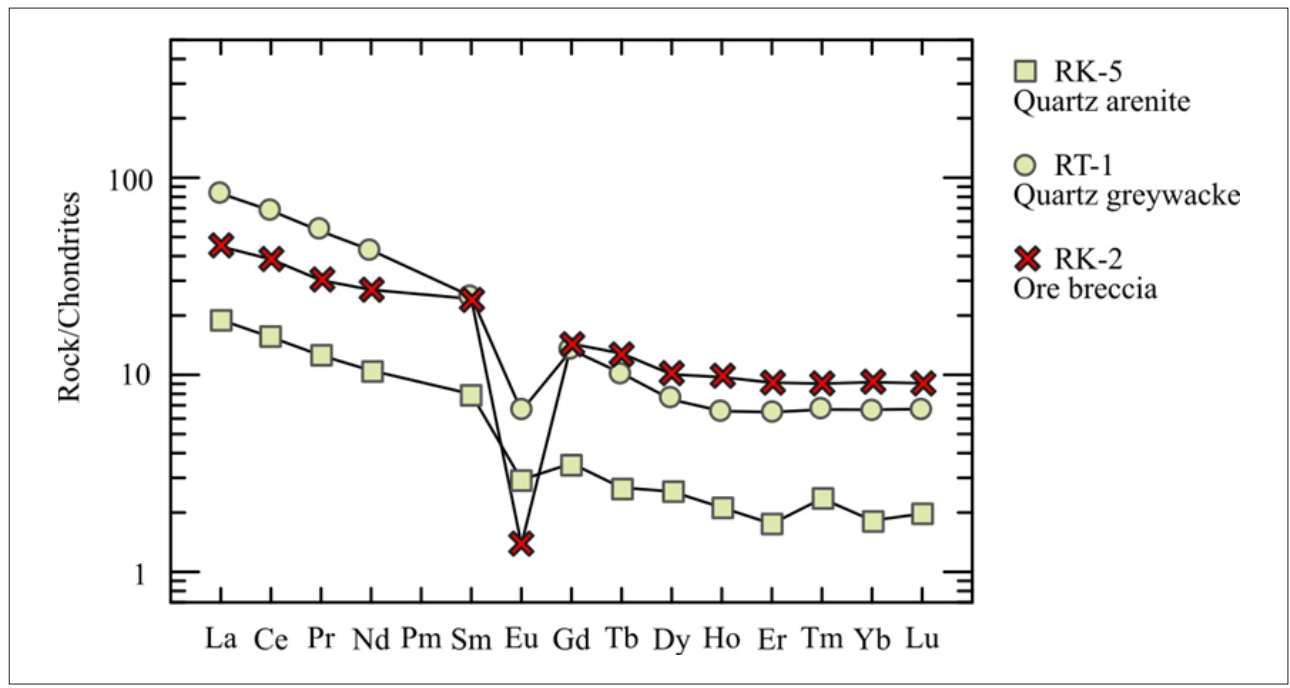

Figure 14: The chondrite normalized (Sun and McDonough, 1989) REE patterns of samples RK-2, RK-5 and RT-1

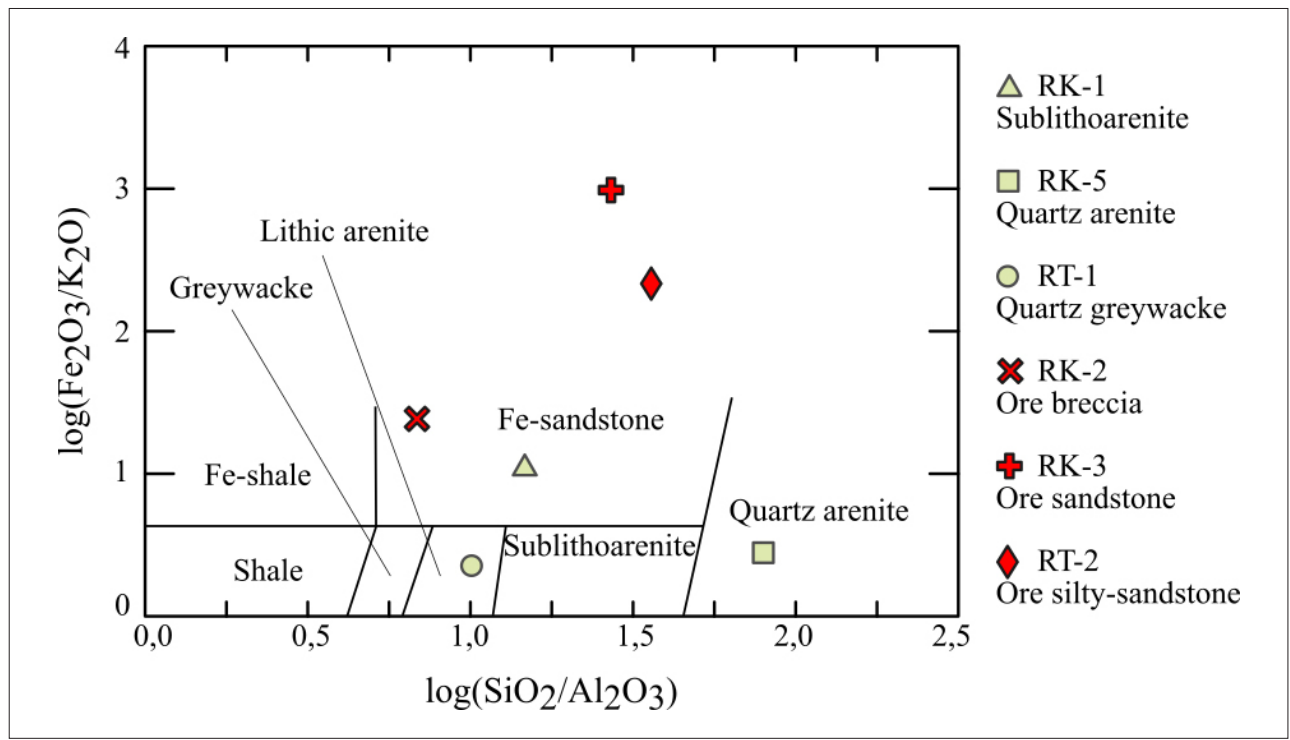

Figure 15: Chemical classification of studied sandstones based on the ratios of major elements: $\log \left(\mathrm{SiO}_{2} / \mathrm{Al}_{2} \mathrm{O}_{3}\right)$ versus $\log \left(\mathrm{Fe}_{2} \mathrm{O}_{3} / \mathrm{K}_{2} \mathrm{O}\right)$ (Herron, 1998)

continental crust. Samples of RK-1 sublithoarenite, RK-3 ore sandstone, and RT-2 ore silty-sandstone have a much lower concentration of REE, up to 30 times enriched relative to chondrite, and a positive Eu anomaly. This trend is most probably caused by hydrothermal fluids rich in $\mathrm{CO}_{3}{ }^{2-}$-ion, which mobilized all rare earth elements except Eu.

\subsection{Weathering conditions}

All samples except RT-2 ore silty sandstone have a relatively high Chemical Index of Alteration (CIA), being calculated as $\left[\mathrm{Al}_{2} \mathrm{O}_{3} /\left(\mathrm{Al}_{2} \mathrm{O}_{3}+\mathrm{CaO}^{*}+\mathrm{Na}_{2} \mathrm{O}+\mathrm{K}_{2} \mathrm{O}\right)\right] \mathrm{x}$ 100 , where $\mathrm{CaO}^{*}$ represents $\mathrm{CaO}$ incorporated in the silicate fraction of the rock. The calculated CIA values vary between 52.1 and 81.3 indicating a high level weathering of source rocks (see Table 1). The weathering intensity of source rocks can also be read from the A-CN-K diagram in Figure 17, proposed by Nesbitt and Young (1984, 1989). Most of the samples are projected on the right side of diagram in the area with high $\mathrm{Al}_{2} \mathrm{O}_{3}$ ratios. This area is typical for the intense weathering of granite rock. The RT-2 ore silty sandstone is projected in the area of poorly weathered rocks of tonalitic composition, and the RK-3 ore sandstone in the area of the highly weathered gabbroic rock. However, the positions in the A-CN-K diagram of all samples that has been exposed to the appreciable hydrothermal alteration should be taken with caution.

The presence of heavy minerals tourmaline, zircon and opaque minerals in the samples RK-1 sublithoarenite and RT-1 quartz greywacke leads to the assumption 


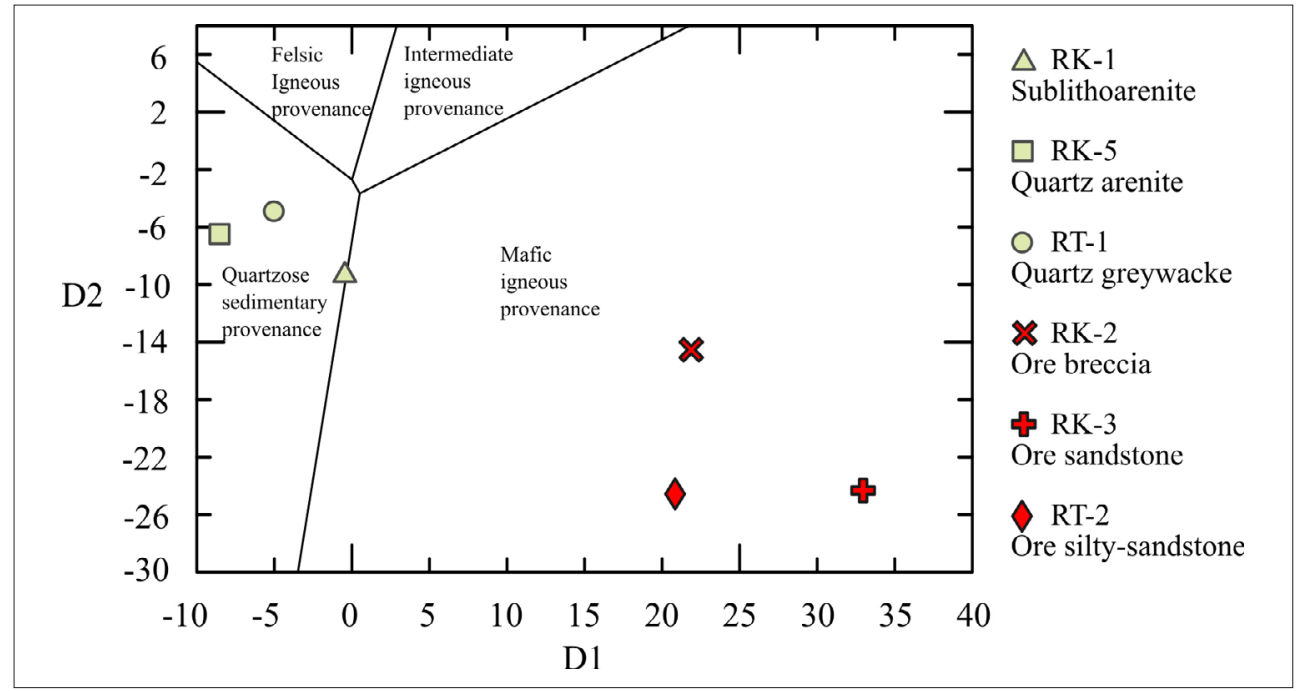

Figure 16: Provenance identification diagram using major element ratios (Roser and Korsch, 1988). $\mathrm{D} 1=-1,773 \times \mathrm{TiO}_{2}+0,607 \times \mathrm{Al}_{2} \mathrm{O}_{3}+0,76 \times \mathrm{Fe}_{2} \mathrm{O}_{3}-1,5 \times \mathrm{MgO}+0,616 \times \mathrm{CaO}+0,509 \times \mathrm{Na}_{2} \mathrm{O}$ $-1,224 \times \mathrm{K}_{2} \mathrm{O}-9,09 . \mathrm{D}_{2}=0,445 \times \mathrm{TiO}_{2}^{2}+0,07 \times \mathrm{Al}_{2} \mathrm{O}_{3}-0,25 \times \mathrm{Fe}_{2} \mathrm{O}_{3}-1,142 \times \mathrm{MgO}+0,438 \times \mathrm{CaO}$ $+1,475 \times \mathrm{Na}_{2} \mathrm{O}+1,426 \times \mathrm{K}_{2} \mathrm{O}-6,861$.

Table 4: Ratios of immobile elements

\begin{tabular}{|l|c|c|c|c|c|c|c|c|c|}
\hline Sample & RK-1 & RK-2 & RK-3 & RK-5 & RT-1 & RT-2 & Acid rock & Basic rock & UCC \\
\hline $\begin{array}{c}\text { Sublitho- } \\
\text { arenite }\end{array}$ & $\begin{array}{c}\text { Ore } \\
\text { breccia }\end{array}$ & $\begin{array}{c}\text { Ore } \\
\text { sandstone }\end{array}$ & $\begin{array}{c}\text { Quartz } \\
\text { arenite }\end{array}$ & $\begin{array}{c}\text { Quartz } \\
\text { greywacke }\end{array}$ & $\begin{array}{c}\text { Ore-silty } \\
\text { sandstone }\end{array}$ & $\begin{array}{c}\text { Cullers and } \\
\text { Berendsen } \\
\text { (1998) }\end{array}$ & $\begin{array}{c}\text { Cullers and } \\
\text { Berendsen } \\
\text { (1998) }\end{array}$ & $\begin{array}{c}\text { McLennon } \\
(\mathbf{2 0 0 1})\end{array}$ \\
\hline $\mathbf{L a / S c}$ & 6.2 & 1.8 & 3.4 & $>4.5$ & 3.9 & 0.9 & $2.5-16.3$ & $0.43-0.86$ & 2.2 \\
$\mathbf{T h} / \mathbf{S c}$ & 2.4 & 1.3 & 1.6 & $>1.4$ & 1.6 & 1.5 & $0.8-20.5$ & $0.05-0.22$ & 0.8 \\
$\mathbf{L a / C o}$ & 0.3 & 9.6 & 2.0 & 22.5 & 1.8 & 0.3 & $1.8-13.8$ & $0.14-0.38$ & 1.8 \\
$\mathbf{T h} / \mathbf{C o}$ & 0.1 & 7.0 & 0.9 & 7.0 & 0.7 & 0.5 & $0.04-3.25$ & $0.04-1.40$ & 0.6 \\
$\mathbf{C r} / \mathbf{T h}$ & 22.8 & 6.2 & 17.1 & 9.8 & 3.5 & 6.8 & $4.0-15.0$ & $25-500$ & 7.8 \\
$\mathbf{T h} / \mathbf{U}$ & 2.7 & 3.5 & 3.2 & 2.8 & 4.6 & 4.3 & $>4$ & $<4$ & \\
$\mathbf{L a} / \mathbf{T h}$ & 2.6 & 1.4 & 2.1 & 3.2 & 2.5 & 0.6 & & & \\
$\mathbf{T h} / \mathbf{C r}$ & 0.0 & 0.2 & 0.1 & 0.1 & 0.3 & 0.1 & & \\
\hline
\end{tabular}

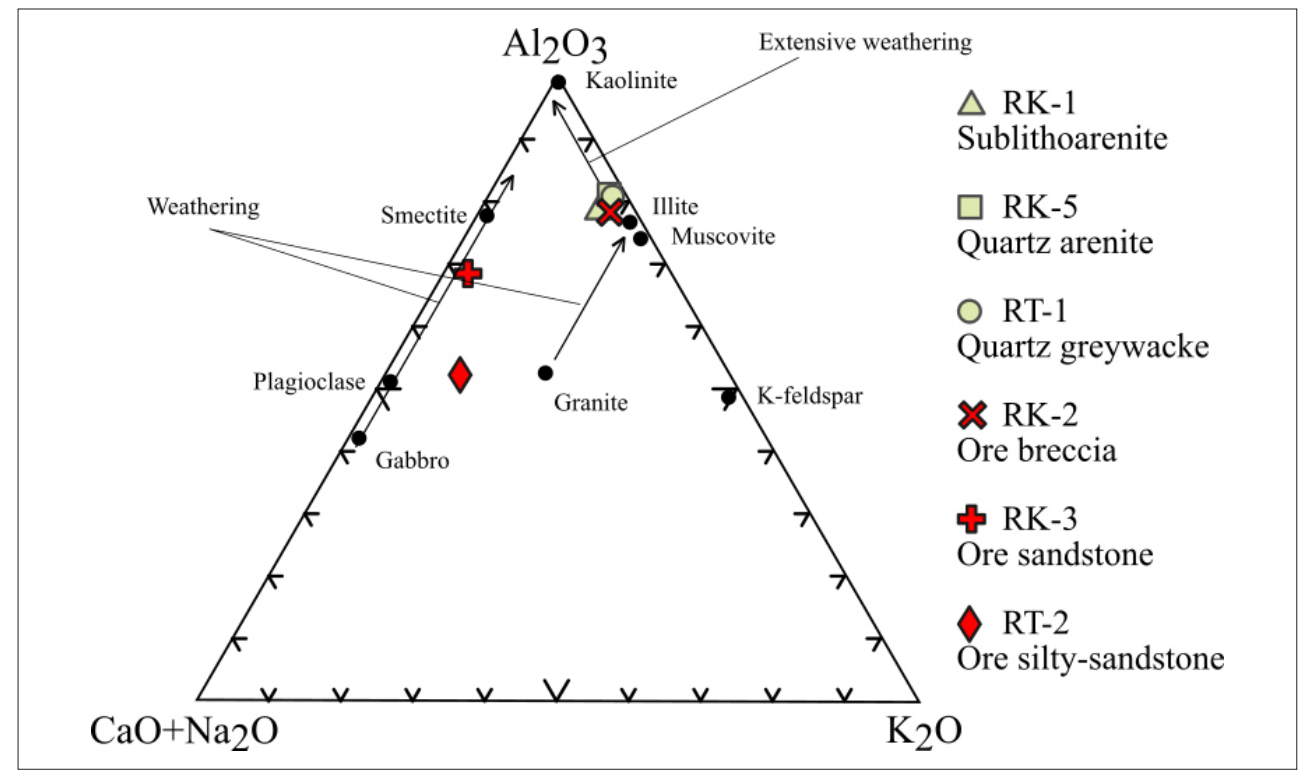

Figure 17: Evaluation of the chemical weathering trends of studied rocks in A-CN-K ternary diagram, (Nesbitt and Young, 1984, 1989) 


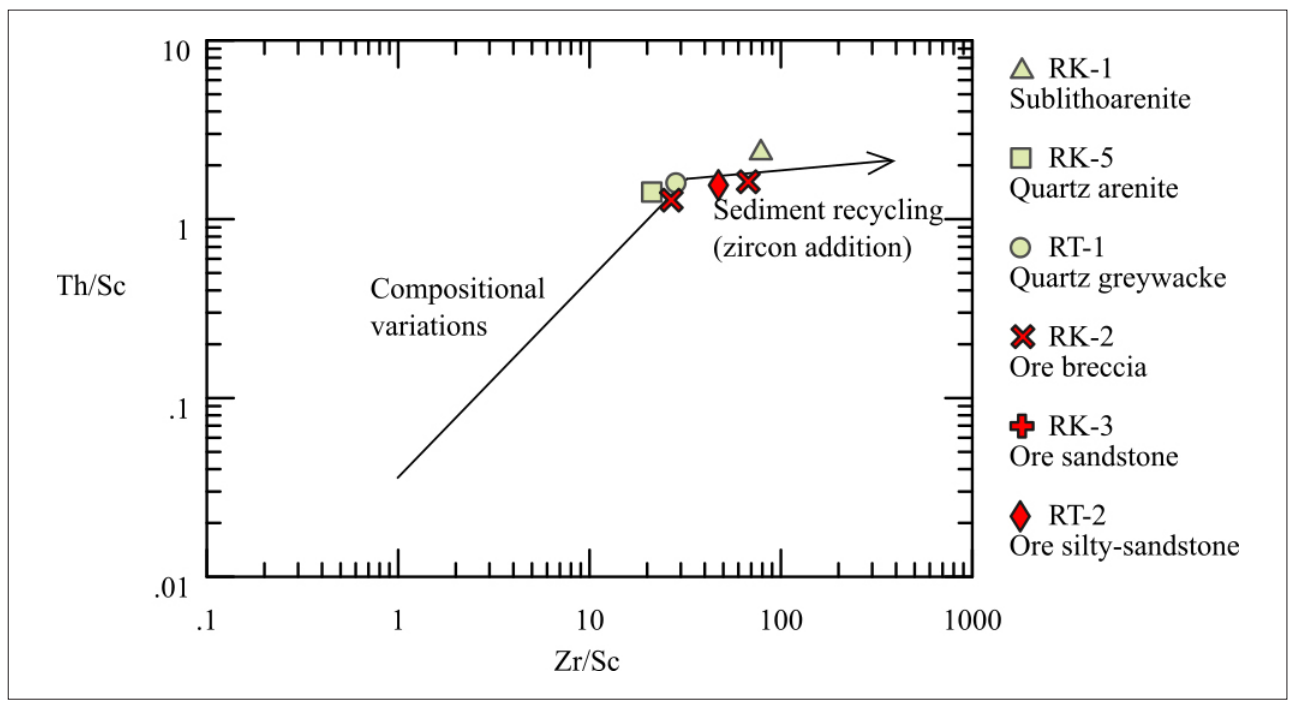

Figure 18: Th/Sc versus $\mathrm{Zr} / \mathrm{Sc}$ diagram showing recycling trend of all samples

(McLennan et al, 1993)

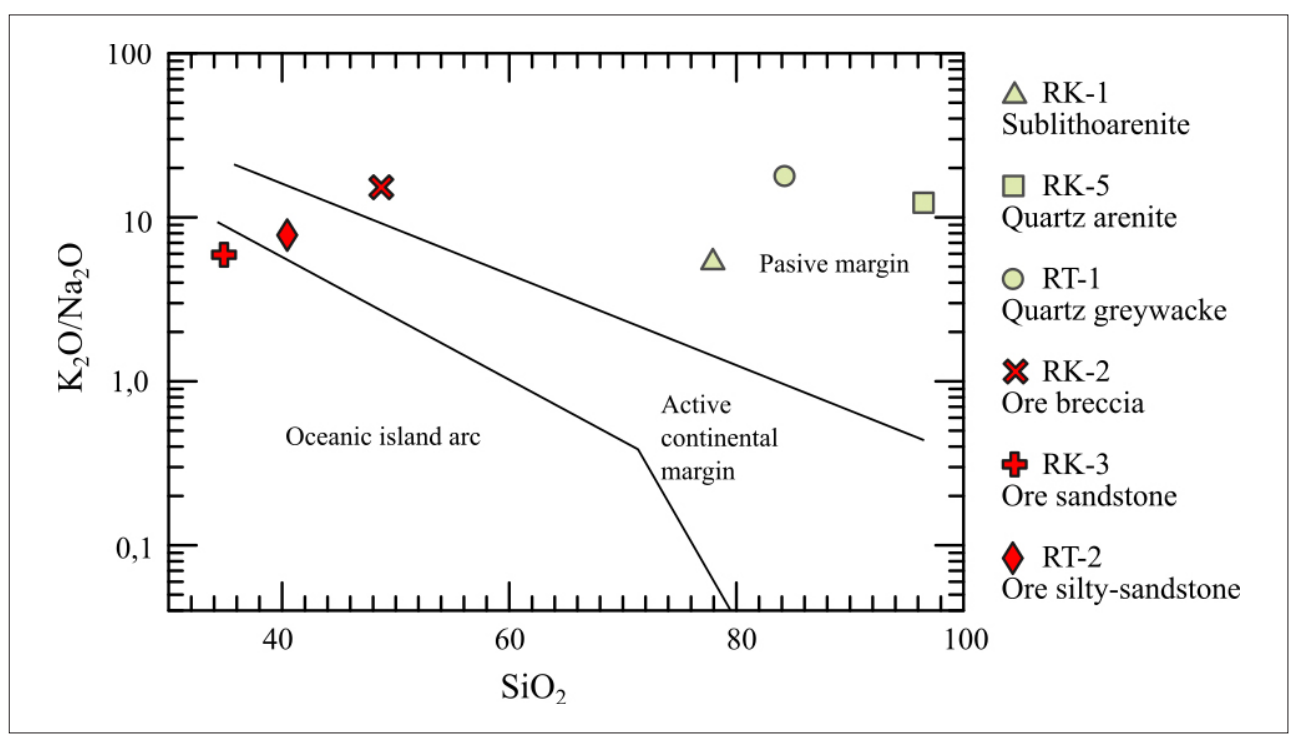

Figure 19: Geotectonic position of sedimentation basin based on the $\mathrm{K}_{2} \mathrm{O} / \mathrm{N}_{2} \mathrm{O}-\mathrm{SiO}_{2}$ ratio,

(Roser and Korsch, 1986)

that the sediments went through extensive sorting regimes, or the possible resedimentation of hard rock. This can be also seen from the $\mathrm{Th} / \mathrm{Sc}$ versus $\mathrm{Zr} / \mathrm{Sc}$ diagram (McLennan et al., 1993), (Figure 18). All samples are well aligned with the sediment recycling trend.

\subsection{Tectonic setting}

Petrographic analysis did not identify fragments of magmatic rocks, so it can be concluded that the sedimentary basin was most likely located on the passive margin. This assumption is supported by the results of the chemical analysis, using the ratio of $\mathrm{K}_{2} \mathrm{O} / \mathrm{Na}_{2} \mathrm{O}$ versus $\mathrm{SiO}_{2}$ (Roser and Korsch, 1986), shown in Figure 19. The least hydrothermal modified samples RT-1 quartz greywacke and RK-5 quartz arenite, as well as two others (RK-1 sublithoarenite, RK-2 ore breccia) are projected into the passive margin area, so it can be concluded that the examined sandstones have been formed by the weathering of continental, most likely recycled sediment material. Other samples (RK-3 ore sandstone and RT-2 ore silty sandstone) are projected in the area of ocean island arcs and active continental margin, which is not a realistic picture. The reason could be that the primary quartz-sericite matrix is suppressed by secondary siderite and hematite cement, thereby significantly reducing the $\mathrm{SiO}_{2}$ concentration, and thus the position of the samples on the diagram moves to the left in the area of more basic rocks. The explanation lies in the fact that primary rocks were almost completely altered by secondary hydrothermal events, which have decreased $\mathrm{SiO}_{2}$ content and enriched rocks in $\mathrm{FeO}$ content. 


\section{Conclusions}

From petrographic and geochemical analyses, it can be concluded that most of the investigated sandstones are hydrothermally modified. The least modified sample RT-1, taken from the position farthest from the former ore body, is classified as quartz greywacke, the RK-5 sample as a quartz arenite, and the RK-1 sample as sublithoarenite. The samples showing pronounced hydrothermal alterations RK-2, RK-3 and RT-2 are classified as ore breccia, ore sandstone and ore silt-sandstone, respectively.

The weathering of parent rocks was very intense, CIA up to $81.3 \%$ for most rocks. The source rocks of the investigated sandstones were felsic, most likely sedimentary and possibly resedimented. The sedimentary basin was probably located on a passive continental margin.

\section{Acknowledgment}

Financial resources for making this scientific work are provided by The Ministry of Science, and Education of the Republic of Croatia in the scope of scientific project: „Magmatizam i mineralna ležišta Dinarskog krškog područja“, no. 195-1953068-3206.

\section{References}

Aubouin, J., Blanchet, R., Cadet, J-P., Celet, P., Charvet, J., Chorowicz, J., Cousin, M., Rampnoux, J-P. (1970): Essai sur la géologie des Dinarides (Essay on the geology of the Dinarides). Bulletin de la Société géologique de France, 7, XII/6, 1060-1095. (In French)

Bhatia, M. R. (1983): Plate tectonics and geochemical composition of sandstones. Journal of Geology, 91, 611-627.

Csontos, L., Nagymarosy, A., Horváth, F., Kovác, M. (1992): Tertiary evolution of the Intra-Carpathian area: a model. Tectonophysics, 208, 221-241.

Cullers, R. L., Berendsen, P. (1998): The provenance and chemical variation of sandstones associated with the MidContinent Rift system, USA. European Journal of Mineralogy, 10, 987-1002.

Gorjanović-Kramberger, D. (1884): Palaeontološki prilozi (Palaeontological contributions). Rad Jugoslavenske akademije znanosti i umjetnosti, knjiga LXXII, Zagrerb. (in Croatian)

Hacquet, B. (1784): Oryctographia carniolica, oder physikalische Erdbeschreibung des Herzogthums Krain, Istrien und zum Theil der benachbarten Lander (Oryctographia carniolica or physical geography of Duch Kranj, Istria and partly of adjacent countries). III Teil. Leipzig. 184 p. (in German)

Herak, M. (1956): Geologija Samoborske gore (Geology of Samoborska Gora Mt.). Acta geologica, 1, JAZU, Zagreb, 49-72. (in Croatian)

Herron M. M. (1988): Geochemical classification of terrigenous sands and shales from core or log data. Journal of Sedimentary Petrology, Vol. 58, 5, 820-829.
Lužar-Oberiter, B., Mikes, T., Dunkl, I., Babić, Lj. Eynatten, H. (2012): Provenance of Cretaceous synorogenic sediments from the NW Dinarides (Croatia). Swiss Journal of Geosciences, 105, 377-399.

McLennan, S. M., Hemming, S., McDaniel, D.K., Hanson, G.N. (1993): Geochemical approaches to sedimentation, provenance and tectonics. Geological Society of America Special Papers, 285, $21-40$.

McLennan, S. M. (2001): Relationships between the trace element composition of sedimentary rocks and upper continental crust: Geochemistry Geophysics Geosystems, 2, 1021-1024.

Nesbitt, H. W., Young, G. M. (1984): Prediction of some weathering trends of plutonic and volcanic rocks based upon thermodynamic and kinetic considerations. Geochimica et Cosmochimica Acta, 48, 7, 1523-1534.

Nesbitt, H. W., Young, G. M. (1989): Formation and diagenesis of weathering profiles. Journal of Geology, 97, 129 - 147.

Palinkaš, L. A. Borojević Šoštarić, S., Strmić Palinkaš, S., Prochaska, W., Spangerberg, J., Cuna, S., Šinkovec, B. (2010): Permian-polysulphide-siderite-barite-haematite deposit Rude in Samoborska Gora Mts., Zagorje-Transdanubian zone of the Inner Dinarides. Geologia Croatica, 63, 1, 93-115.

Pamić, J. (1993): Eoalpine to Neoalpine magmatic and metamorphic processes in the northwestern Vardar Zone, the easternmost Periadriatic Zone and the southwestern Pannonian Basin. Tectonophysics, 226, 503-518.

Pamić, J., Gušić, I., Jelaska, V. (1998): Geodynamic evolution of the Central Dinarides. Tectonophysics, 297, 251-268.

Pettijohn, F. J., Potter, P. E., Siever, R. (1987): Sand and sandstone. Springer-Verlag, New York. 553 p.

Rahman, M. J. J., Suzuki, S. (2007): Geochemistry of sandstones from the Miocene Surma Group, Bengal Basin, Bangladesh: Implications for Provenance, tectonic setting and weathering. Geochemical Journal, 41, 415-428.

Roser, B. P., Korsch, R. J. (1986): Determination of tectonic setting of sandstone-mudstone suites using $\mathrm{SiO}_{2}$ content and $\mathrm{K}_{2} \mathrm{O} / \mathrm{Na}_{2} \mathrm{O}$ ratio. Journal of Geology, 94, 635-650.

Roser, B. P., Korsch, R. J. (1988): Provenance signatures of sandstone-mudstone suites determined using discriminant function analysis of major-element data. Chemical Geology, 67, 119-139.

Slovenec, D., Bermanec, V. (2006): Sistematska mineralogijamineralogija silikata (Systematic mineralogy-mineralogy of silicates). Denona, Zagreb. 359 p. (in Croatian).

Sun, S. S., McDonough, W.F. (1989): Chemical and isotopic systematics of oceanic basalts: implications for mantle composition and processes. Geological Society, London, Special Publication, 42, 313-345.

Šikić, K., Basch, O., Šimunić, A., (1972): Tumač za Osnovnu geološku kartu SFRJ, list Zagreb (Basic geological map of SFRJ, Geology of Zagreb). Savezni geološki zavod, Beograd. (in Croatian)

Šinkovec, B. (1956): Situacioni nacrt i geološko-jamska karta Rude kod Samobora 1:1000 (Situational plan and geological-mine pit map of Rude near Samobor 1:1000). Zavod za geološka istraživanja N. R. H. Zagreb. 
Šinkovec, B. (1971): Ležišta željezne i bakarne rude u Rudama (Iron and copper ore deposits in Rude). Geološki vjesnik, 24, 165-181. (in Croatian - English abstract)

Taylor, S. R., McLennan, S. M. (1985): The continental crust: its composition and evolution: an examination of the geochemical record preserved in sedimentary rock. Blackwell scientific, 312 p., Oxford

Tomljenović, B. (2002): Strukturne značajke Medvednice i Sasmoborskog gorja (Structural features of Mt. Medvednica and Mt. Samoborska gora). Dissertation, University of Zagreb, 208 p. (in Croatian - English abstract)

Vernooij, M. G. C., Langenhorst, F. (2005): Experimental reproduction of tectonic deformation lamellae in quartz and comparison to shock-induced planar deformation features. Meteoritic and Planetary Science, 40, 9/10, 1353-1361.
Vukotinović, L. (1855): Eisenwerk Rude bei Samobor (Ironworks Rude near Samobor). Jahrbuch der Geologischen Reichsanstalt, 6, 166, Wien. (in German)

Vukotinović, L. (1873a): Kupfer- und Eisensteinbergbau in Rude bei Samobor (Cooper and ironstone mining in Rude near Samobor). Österreichische Zeitschrift für Berg- und Hüttenwesen, 8, 59-60. (in German)

Vukotinović, L. (1873b): Rude bei Samobor in Croatien (Rude near Samobor in Croatia). Verhandlungen der Geologischen Reichsanstalt, 2, 26-30. Wien. (in German)

Willingshofer, E., (2000): Extension in collisional orogenic belts: the Late Cretaceous evolution of the Alps and Carpathians. Doctoral thesis, Vrije University, Amsterdam, $146 \mathrm{p}$.

\section{SAŽETAK}

\section{Petrološke karakteristike klastičnih taložnih stijena iz rudnika Sveta Barbara u Rudama kraj Samobora}

U okviru ovoga istraživanja napravljene su petrografske i geokemijske analize klastičnih taložnih stijena iz rudnika bakra i željeza Sveta Barbara u Rudama kraj Samobora s ciljem da se klasificira i odredi podrijetlo sedimenata, kao i okolina formiranja klastičnih taložnih stijena te utjecaj hidrotermalnih fluida na njihova svojstva. Ukupno je prikupljeno osam uzoraka s različitih lokaliteta unutar rudnika, od čega je šest uzoraka detaljno analizirano. Rezultati su pokazali strukturnu i geokemijsku varijabilnost i nejednak intenzitet hidrotermalne alteracije u uzorcima. Na temelju petrografske analize tri stijene klasificirane su kao sublitoarenit, kvarcni arenit i kvarcna grauvaka. Tri uzorka klasificirana su kao orudnjena breča, orudnjeni pješčenjak i orudnjeni siltozni pješčenjak zbog izrazite hidrotermalne alteracije i rudne mineralizacije. Petrografske i geokemijske analize pokazuju da su ishodišne stijene istraživanih klastičnih sedimenata bile felzične $(\mathrm{La} / \mathrm{Sc}=0,9-6,2 ; \mathrm{Th} / \mathrm{Sc}=1,3-2,4)$, najvjerojatnije taložne, i moguće pretaložene. Stupanj trošenja ishodišnih stijena bio je vrlo visok (kemijski indeks alteracije - CIA $=52,1-81,3 \%$ ), a geotektonska pozicija sedimentnoga bazena vrlo je vjerojatno bila na pasivnome kontinentalnom rubu.

\section{Ključne riječi:}

klastične taložne stijene, petrografija i kemizam stijena, podrijetlo sedimenta, rudnik Sveta Barbara u Rudama, Samoborsko gorje

\section{Author's contribution}

This paper is based on the results obtained in the scope of investigation for Bachelor thesis of principal researcher Šime Bilić (1) (Mag. of Geology, Assistant, PhD student at the Faculty of Mining, Geology and Petroleum Engineering, University of Zagreb, Petrology and Geochemistry). He collected the samples in the field, provided petrographic investigations and presentation of geochemical data in tables and diagrams and wrote the manuscript. Vesnica Garašić (2) (Ph.D., Associate Professor at the Faculty of Mining, Geology and Petroleum Engineering, University of Zagreb, Petrology and Geochemistry), the supervisor of Bachelor thesis provided funding for the field work and geochemical analyses, participated in the field work, provided suggestions in the interpretation of the research results and graphic representations of data and participated in the writing of the discussion and conclusion sections. 